\title{
Petrography and geochemistry of Palaeozoic quartz-rich sandstones from Saudi Arabia: implications for provenance and chemostratigraphy
}

\author{
Alexander Bassis ${ }^{1,}{ }^{,}$, Matthias Hinderer ${ }^{1}$, Guido Meinhold ${ }^{2}$ \\ ${ }^{1}$ Institute of Applied Geosciences, Darmstadt Technical University, Schnittspahnstraße 9, \\ 64287 Darmstadt, Germany \\ 2 Department of Sedimentology and Environmental Geology, Geoscience Center, \\ University of Göttingen, Goldschmidtstraße 3, 37077 Göttingen, Germany
}

Corresponding author: alex.bassis@hotmail.com (Alexander Bassis)

\begin{abstract}
The Arabian Peninsula hosts a thick Palaeozoic succession, ranging from the Cambrian through the Permian. It not only contains deposits of the two major Palaeozoic glaciations but also holds both the major Palaeozoic hydrocarbon source and reservoir rocks. In addition, Palaeozoic sandstones serve as important aquifers. The succession is dominated by highly mature quartz arenites, as seen in thin sections. It is starved of fossils and very uniform in lithology. In order to better understand provenance, tectonic setting and stratigraphic relationships, the petrography as well as major and trace element geochemistry of sandstones were studied. Samples were taken from two study areas in southern (Wajid area) as well as central and northern (Tabuk area) Saudi Arabia. The dataset we present here is the first comprehensive study to cover the entire Palaeozoic succession in both the southern and northern part of the Arabian Peninsula. The collisional signal from some samples is a relic from the last stages of the amalgamation of Gondwana, carried into the basin by glaciogenic sediments. Major and trace element geochemistry indicate the Neoproterozoic basement of the nearby Arabian Shield as the most likely source for the detritus. Tectonic discrimination diagrams suggest that deposition of sandstones took place in an intracratonic setting, which is in accordance with the established model for the evolution of the Arabian Plate. An influx of fresh material, probably sourced from the Shield, did occur in the late Palaeozoic units of the Wajid area but did not reach the Tabuk area. Geochemical methods have shown some success in characterising the provenance of both study areas but were unable to reliably assess sedimentary recycling. A (meta-)sedimentary source for the Palaeozoic sandstones could therefore neither be proven nor refuted. Multivariate cluster and principal component analysis of geochemical data revealed significant differences between the two study areas.
\end{abstract}




\section{Keywords}

Saudi Arabia, Palaeozoic, Sandstone, Provenance, Petrography, Geochemistry, Chemostratigraphy

\section{Introduction}

Saudi Arabian Palaeozoic sediments have been and are still intensely studied since the 1950s (e.g. Thralls and Hasson 1956; Powers et al. 1966; BRGM 1985; McGillivray and Husseini 1992; Stump et al. 1995; Alsharhan and Nairn 1997; Edgell 1997; Sharland et al. 2001; GTZ/DCo 2009; Al-Ajmi et al. 2015), both for economic and scientific reasons. They not only represent significant source and host rocks for hydrocarbons but also recently gained importance as groundwater reservoirs (Schubert et al. 2011; Al-Ajmi et al. 2014; Salman et al. 2014) for the increasing demands of the desert kingdom.

The Arabian Plate hosts a thick Palaeozoic clastic sedimentary succession. Palaeozoic sediments crop out in a narrow band east of the Arabian Shield (Fig. 1a). The Palaeozoic siliciclastics show great hydrocarbon and groundwater reservoir potential in the subsurface (Al-Ajmi et al. 2015). They are dominated by highly mature clastic sediments, which are overall devoid of fossils. Saudi Arabian Palaeozoic stratigraphy still mainly relies on lithostratigraphic correlations, which can be unreliable in such extensive, highly mature successions. Other successful stratigraphic tools are heavy mineral stratigraphy and chemostratigraphy, which so far have only been applied by a few workers and often only for individual Palaeozoic units (Powers et al. 1966; Hussain 2001; Hussain and Abdullatif 2004; Al-Harbi and Khan 2005; Hussain 2007; Knox et al. 2007, 2010; Al-Harbi and Khan 2008, 2011). A comprehensive database, covering the entire Palaeozoic succession on a regional scope and combining petrographic and geochemical data, is still lacking.

Since the early 2000s, there have been several studies concerning the provenance of those sediments, employing and combining standard techniques like petrographic, geochemical and heavy mineral analyses. While the Wajid area has been studied previously, data from most of the Palaeozoic in central and northern Saudi Arabia are still lacking. So far, the majority of publications identified acidic igneous rocks from southern terrains, probably in Yemen, as the primary source for sediments of the Wajid Group (Babalola 1999; Hussain et al. 2000; Hussain 2001; Hussain et al. 2004; Wanas and Abdel-Maguid 2006; Hussain 2007; Knox et al. 2007). Secondary sources include metamorphic, metasedimentary and recycled sedimentary rocks, to varying degrees. A southerly provenance is supported by palaeocurrent data according to Babalola (1999), Hussain (2001) and Hussain et al. (2000). Yet, at least for the Wajid area, a homogenous northward transport direction cannot be inferred for the entire Palaeozoic succession. Opposing (northwest to southeast) transport directions in the glaciogenic units of the Sanamah and Juwayl formations have been interpreted in recent studies (Hinderer et al. 2009; Keller et al. 2011; Al-Ajmi et al. 2015). They also indicated the Arabian-Nubian Shield (ANS) as a possible source area for the 
Juwayl Formation. Employing standard petrographic methods and major element geochemistry, Al-Harbi and Khan $(2005,2008,2011)$ established the ANS as the primary source for sediments of the Sarah, Tawil and Unayzah formations in central and northern Saudi Arabia. In contrast, Knox et al. (2010) identified a recycled sedimentary source to the south as the primary contributor for the Unayzah Formation by studying heavy mineral assemblages. All studies were concordant in assigning an intracratonic or passive margin depositional setting to Palaeozoic sandstones in both southern and northern/central Saudi Arabia.

Stratigraphic correlation of clastic successions by means of geochemical characteristics has been shown to yield promising results and is an increasingly important tool (Weibel et al. 2010). So far, only one publication (Hussain 2007) dealt with a geochemical approach to stratigraphic correlation. This study was constrained to the Early Palaeozoic lower Wajid Group and the Saq and Qasim formations. Although several workers utilised geochemical data in provenance studies, there has been no published effort to establish geochemical correlations for Palaeozoic sandstones from the Arabian Peninsula.

Despite more than half a decade of research, there still remain some questions to be addressed in this study:

(1) What is the provenance of this highly mature siliciclastic succession?

(2) How can the different sandstone units in southern, central and northern Saudi Arabia be correlated?

This paper aims to provide new answers to these questions. We present the first comprehensive dataset, containing petrographic data from thin sections as well as major and trace element geochemistry, covering the entire Palaeozoic successions in both southern and central/northern Saudi Arabia.

\section{Geological framework}

\section{Arabian plate evolution}

During the final stages of the Pan-African Orogeny in the late Neoproterozoic, a collage of juvenile arcs and enclaves of pre-Neoproterozoic crust attached onto Gondwana, forming the Arabian-Nubian Shield (ANS), which makes up a prominent part of the basement of the Arabian Plate (e.g. Johnson et al. 2011). After final amalgamation of the supercontinent, a vast depositional platform developed on its northern (in present-day coordinates) passive margin. This sedimentary system stretched over modern-day North Africa, Turkey, Iran and the Arabian Peninsula. During the early Palaeozoic, especially the Cambrian-Ordovician, a vast amount of highly mature sandstones were deposited (Avigad et al. 2005). Squire et al. (2006) postulated a super-fan system which has been confirmed to have reached Libya and 
southern Jordan (Meinhold et al. 2013a). Throughout most of the Palaeozoic, the Arabian Platform was situated further inland from the passive margin to the north and east, thus representing an intracratonic setting. Beginning subduction of the Palaeo-Tethys under these blocks in the Late Devonian caused a switch to a back-arc setting in the northern and eastern parts of the Arabian Platform (McGillivray and Husseini 1992; Sharland et al. 2001). Low subsidence rates and the high stability of the Arabian Plate throughout most of the Palaeozoic resulted in a 'layer cake' stratigraphy (Bishop 1995). Sediments were deposited mostly in fluvial to shallow marine conditions. Accommodation was largely controlled by eustacy (Sharland et al. 2001).

At the beginning of the Palaeozoic, much of northern Gondwana had been peneplained. On the Arabian Plate existed a broad clastic shelf, adjacent to exposed Pan-African basement rocks of the ANS. On this peneplain, mature quartz arenites were deposited (Konert et al. 2001). In the Late Ordovician, Gondwana had moved further south, moving the Arabian Plate into palaeo-latitudes of $40^{\circ} \mathrm{S}$ to $60^{\circ} \mathrm{S}$ (Sharland et al. 2001). This brought Arabia into reach of the polar ice cap of the Hirnantian glaciation, causing sub-glacial erosion across the platform (Vaslet 1990; Keller et al. 2011). Tunnel valleys, radiating away from the ANS, incised deeply into platform sediments (Sharland et al. 2001; Le Heron et al. 2009). With the demise of the Hirnantian ice-age, sea-level rapidly rose in response to deglaciation. Anoxic conditions and sediment starvation in the Early Silurian helped create the prolific, organic-rich 'hot shales'. Throughout most of the Devonian, sedimentation took place in an epicontinental, dominantly shallow marine, intra-cratonic setting. Regional uplift and erosion on structural highs associated with the following Hercynian Orogeny in North America and Europe removed large parts of the Devonian strata (McGillivray and Husseini 1992; Sharland et al. 2001; Al-Ramadan et al. 2004; Al-Laboun 2013). The CarboniferousPermian brought with it the second large Palaeozoic glaciation of Gondwana. Glacial and peri-glacial sediments were deposited on the Hercynian ('pre-Unayzah') unconformity (Le Heron et al. 2009; Keller et al. 2011). Glacial advance was towards the north and northwest in northern Arabia and to the south and southeast in southern Arabia, away from the main ice shield, as evidenced by direction of tunnel valleys and striated surfaces (Hinderer et al. 2009; Khalifa 2015). Palaeozoic clastic sedimentation ceased with the deposition of the Late Permian Khuff carbonate rocks.

\section{Northern and central Saudi Arabian stratigraphy}

Northern Saudi Arabian Palaeozoic stratigraphy underwent several re-definitions and revisions in the last 60 years (see Powers et al. 1966; Al-Laboun 1993; Stump et al. 1995; AlLaboun 2010; SGS 2013). This paper follows the nomenclature established by Al-Laboun (2010) and SGS (2013), with slight adjustments to the chronostratigraphy (Fig. 2). Outcrops can be found along the eastern to north-eastern edge of the Arabian Shield and further north around the cities of Sakaka and Dawmut al Jandal (Fig. 1c). 


\section{Saq Formation}

The Saq Formation is of (Middle) Cambrian to Middle Ordovician age, deposited between 520 and $465 \mathrm{Ma}$. The Saq Formation is of uniform lithology, consisting of dominantly poorlyto well-sorted and cross-bedded, mature quartz sandstone (Powers et al. 1966). It was deposited in a braided fluvial to shallow marine environment (Hussain and Abdullatif 2004; Hussain 2007; SGS 2013). Its Cambrian to Ordovician age mainly rests on the stratigraphic context (Powers et al. 1966; SGS 2013). Parts of the Saq Formation are considered to be the equivalent of the southern Arabian Dibsiyah Formation (Fig. 2).

\section{Qasin Formation}

Deposition of the Qasim Formation took place between 465 and $445 \mathrm{Ma}$, from the Middle Ordovician until the onset of the Late Ordovician (Hirnantian) glaciation (SGS 2013; Melvin 2015). Lithology comprises alternating cyclic deposits of thin-bedded, fine-grained sandstone to shale and thick-bedded, massive to cross-bedded sandstone (Powers et al. 1966). The depositional environment alternated between a continental to shallow marine environment and a more distal, deeper marine setting (Sharland et al. 2001). The Qasim Formation has no direct equivalent in the Wajid area (Fig. 2).

\section{Zarqa and Sarah formations}

For the purpose of this paper, the Zarqa and Sarah formations will be treated as one unit, since they are (chrono-) stratigraphically and genetically closely related (Senalp and AlLaboun 2000; Sharland et al. 2001; Al-Laboun 2010). The Zarqa Formation is of Late Ordovician (Ashgillian) age (SGS 2013). Recent research supports a Late Ordovician (Hirnantian) age for the uppermost Sarah Formation (Hints et al. 2015; Le Hérissé et al. 2015; Melvin 2015; Paris et al. 2015a, b; Wellman et al. 2015). The Zarqa Formation consists of typical glacial tillites and finer grained, micaceous sandstones, shales and clayey siltstones, with local soft-sediment deformation (Senalp and Al-Laboun 2000; Sharland et al. 2001; Al-Laboun 2010). The Sarah Formation is generally comprised of fine- to mediumgrained, trough and planar cross-bedded sandstones, which form palaeovalley-fills (AlLaboun 2010; Al-Harbi and Khan 2011). The depositional environment of both formations is distinctly glacial, subglacial and proglacial, as indicated by striated surfaces, dropstones, glaciated pavements, large erosional grooves, diamictites and drag-overturned folds (Senalp and Al-Laboun 2000) and the presence of tunnel valleys (Sharland et al. 2001). There is clear evidence of sedimentary reworking of underlying strata in the Sarah Formation (Le Hérissé et al. 2015; Melvin 2015). Because of the similarities in glaciogenic origin, depositional environment and stratigraphic context, the Sanamah Formation from the 
Wajid area can be confidently assigned as the southern equivalent of the Sarah/Zarqa formations.

Qalibah Formation: Sharawra Member

The Sharawra Member has been firmly assigned as Early to Middle Silurian (Late Llandovery to Wenlock; Al-Hajri and Paris 1998). Its shales and micaceous siltstones and sandstone were deposited in a shallow marine, prodeltaic environment on a broad and extensive epicontinental shelf (Al-Hajri and Paris 1998; Al-Laboun 2009, 2011). Although the Qalibah Formation is also known from the Wajid area, the Sharawra Member has not been found or described in outcrops from the Wajid area.

Tawil Formation

The Tawil Formation is of Late Silurian to Early Devonian age (McGillivray and Husseini 1992; Al-Laboun 2013). Lithology consists of cross-bedded and channelised, fine- to mediumgrained sandstones interbedded with thin siltstones and shales (Al-Harbi and Khan 2008). They were deposited in alternating shallow marine and fluvial braided environments, representing several transgressive-regressive cycles (McGillivray and Husseini 1992; Konert et al. 2001; Al-Laboun 2013). As a consequence of its (litho-) stratigraphic context, the lowermost Khusayyayn Formation can be correlated to be the southern Saudi Arabian equivalent of the Tawil Formation.

Jauf Formation

The age of the Jauf Formation has been well constrained to Early Devonian (Late Pragian to latest Emsian) (Al-Ghazi 2007; Breuer et al. 2015). The Jauf Formation forms a significant non-associated gas reservoir in central Arabia (McGillivray and Husseini 1992). The Jauf Formation consists mainly of silty shales with various thin beds of limestone, dolomite, gypsum and rarely very thin beds of fine-grained sandstones (Powers et al. 1966). Its depositional environment ranges from shallow marine shelf conditions, over a marginal marine to a continental delta and delta-front setting (Stump et al. 1995; Al-Ghazi 2007). The upper part of the Khusayyayn Formation has been correlated with the lowermost part of the Jauf Formation (Stump et al. 1995; Al-Ajmi et al. 2015).

Jubah Formation 
The Jubah Formation is well constrained to the Middle Devonian (Early Eifelian) to Late Devonian (Famennian) and possibly Mississippian (Early Tournaisian) (Al-Hajri et al. 1999; Clayton et al. 2000; Sharland et al. 2001). Lithology of the Jubah Formation is dominated by fine- to medium-grained, well-sorted and thin to medium cross-bedded quartz sandstone, which is interbedded with silty to sandy shales (Meissner et al. 1989; Wender et al. 1998). Deposition took place in a fully siliciclastic shallow marine to continental, probably deltaicfluvial setting (Meissner et al. 1989; Sharland et al. 2001). The Jubah Formation has no equivalent in the Wajid area (Al-Ajmi et al. 2015).

Unayzah Formation

The Unayzah Formation is of Pennsylvanian (Moscovian to Gzhelian) to Middle Permian (Late Kungurian) age (Alsharhan 1994; Senalp and Al-Duaiji 1995; Sharland et al. 2001; Sharland et al. 2004; Stephenson 2004; Melvin et al. 2010). It is the primary hydrocarbon reservoir rock in central Saudi Arabia. Hydrocarbons are sourced from the Silurian 'hot shale' of the Qusaiba Member (McGillivray and Husseini 1992). It consists of various conglomerates, fine- to coarse-grained and cross-bedded sandstones, intercalations of siltstones and shales as well as caliches and nodular anhydrite (Alsharhan 1994; Senalp and Al-Duaiji 1995). The sediments of the lower Unayzah $C$ and $B$ members are results of a glaciofluvial to glaciolacustrine environment (Le Heron et al. 2009). The upper Unayzah A Member was deposited in an alluvial to fluvial environment dominated by braided and meandering streams. The Unayzah Formation equivalent in the Wajid outcrop area is the Juwayl Formation, which correlates with the Unayzah C and B members (Melvin and Norton 2013; Al-Ajmi et al. 2015).

\section{Southern Saudi Arabian stratigraphy}

Southern Saudi Arabian stratigraphy underwent several revisions since the early field works of Steineke et al. (1958) and others (see Powers et al. 1966; Kellogg et al. 1986; Evans et al. 1991; Stump and van der Eem 1995; Al-Laboun 2000; Hussain et al. 2000; SGS 2013; Al-Ajmi et al. 2015). This paper follows the stratigraphy of Al-Ajmi et al. (2015) (Fig. 2). A detailed overview and history of research on the Wajid sandstone is provided by Al-Ajmi (2013). Outcrops can be found between Wadi Ad Dawasir in the north and Hima in the south (Fig. 1b).

Dibsiyah Formation 
The Dibsiyah Formation has been confidently determined to be of Late Cambrian to Early Ordovician age. Lithology consists of mature, medium- to coarse-grained sandstone and pebbly conglomerates, with a few intercalations of finer siliciclastics (Keller et al. 2011; AlAjmi et al. 2015), deposited in a shallow marine environment (Al-Ajmi et al. 2015). The Dibsiyah Formation is the lateral equivalent of the Saq Formation of central and northern Saudi Arabia.

Sanamah Formation

The lithology and sedimentology of the Sanamah Formation clearly indicate a glacial influence, placing it in the context of the Hirnantian glaciation and making it the equivalent of other glacial deposits across northern Africa and Arabia (McClure 1978; Ghienne and Deynoux 1998; Sharland et al. 2001; Ghienne 2003; Ghienne et al. 2003; Le Heron et al. 2004, 2005, 2009, 2010, 2013, 2015). The Sanamah Formation cuts into the underlying Dibsiyah Formation. The lithological inventory of the Sanamah Formation comprises clast and matrix supported conglomerates, medium- to coarse-grained massive sandstones, siltstones and shales. Indicative features such as clasts with chatter marks, striations, fluted surfaces, depositional geometries and certain lithofacies associations support glaciogenic origin (Keller et al. 2011). Direction of ice-flow was towards the southeast, as evidenced by glacial striations and tunnel valleys. The Late Ordovician Zarqa and Sarah formations have been interpreted as the equivalent of the Sanamah Formation (Evans et al. 1991; Stump and van der Eem 1995; Keller et al. 2011; Al-Ajmi et al. 2015).

Qalibah Formation: Qusaiba Member

The Qusaiba Member of the Qalibah Formation is of Rhuddanian to Late Telychian (443.7 to $\sim 22 \mathrm{Ma}$ ) age (Paris et al. 2015a). The 'hot shale' at the base of the Qusaiba Member is of significant economic importance as a source rock for most Palaeozoic hydrocarbon reservoirs not only in Saudi Arabia (Bishop 1995; Alsharhan and Nairn 1997; Sharland et al. 2001) but also in northern Africa as well where it corresponds to the 'hot shale' of the Tanezzuft Formation (Lüning et al. 2000; Meinhold et al. 2013b). Surface lithology consists of an organic-rich marine shale with laminations and interbedded, rippled and ferruginous siltstones with micaceous sandstone at the top (Edgell 1997; Lüning et al. 2000; Al-Laboun 2009). The Qusaiba Member was deposited in an open marine, low-energy environment that developed during the large-scale transgression at the end of the Hirnantian glaciation (Lüning et al. 2000).

Khusayyayn Formation 
The Khusayyayn Formation has been constricted to the Early Devonian (Late Pragian to Emsian). The Khusayyayn Formation consists of a rather uniform succession of medium- to coarse-grained, partly conglomeratic, sandstones with large-scale cross-bedding of shallow marine origin (Al-Ajmi et al. 2008; Al-Ajmi et al. 2015). The regional equivalent of the Khusayyayn Formation is the Jauf Formation (Al-Ajmi et al. 2015).

Juwayl Formation

The youngest formation of the Wajid Group is the Pennsylvanian to Early Permian Juwayl Formation. Lithology is quite diverse and consists of matrix-supported conglomerates, medium- to coarse-grained, massive to cross- and ripple-bedded sandstones as well as siltstones and shales. Prominent glaciogenic features are striated surfaces and clasts, dropstones, boulder pavements and large-scale soft-sediment deformation (Keller et al. 2011). The sediments have been deposited in two distinct, glacio-fluvial settings: The outcrops represent glacially cut valleys, possibly tunnel valleys (Al-Ajmi et al. 2015). In the southern Wajid area, the finer grained sediments have been interpreted as lake deposits from a periglacial lake, covering large parts of the southern Arabian Peninsula and extending into north-eastern Africa (Keller et al. 2011). The Juwayl Formation has been correlated to the Unayzah C and B members on the ground of lithostratigraphic similarities and palynological data (Melvin and Norton 2013). An equivalent to the Unayzah A Member is not exposed/preserved in the Wajid outcrop area (Al-Ajmi et al. 2015).

\section{Methodology}

A total of 44 samples (identifiable by the prefix 'AB-SA'), covering the entire Palaeozoic succession in both study areas, have been obtained. The sample localities are shown in Fig. $1 b, c$; the corresponding geographical coordinates are given in Table 1. Seventeen samples from Al-Ajmi et al. (2015) were additionally used in our analysis and are presented in several graphs (Table 1).

When selecting samples, emphasis was put on fine- to medium-grained sandstones. Chosen samples are representative for their respective formations in most cases. Where possible they were taken from the lower, middle and upper part of each formation, in order to cover the entire stratigraphic range. Exceptions are units where the predominant and representative grain size would be unsuitable for heavy mineral analysis. Therefore, the samples from the Silurian Qusaiba Member of the Qalibah Formation and one sample from the Subbat Member of the Devonian Jauf Formation, which both are predominantly shaly, were taken from medium-grained, sandy intercalations. Samples from the southern study area were mostly taken in the Wajid outcrop area south and southwest of Wadi Ad Dawasir 
(Fig. 1b), from sections already described and logged by Keller et al. (2011) and Al-Ajmi et al. (2015). Three samples were taken near Hima, north of Najran (Fig. 1b). The central and northern Arabian study area is geographically more extensive with most samples taken from the Buraida area, around Hail and from the vicinity of Sakakah (Fig. 1c).

Sample preparation was performed at Darmstadt Technical University unless stated otherwise. All samples were first cut with a rock saw to prepare thin section slices, while half of the remaining material was then crushed by a jaw crusher. The remaining uncrushed half was retained as backup. Samples for geochemical analysis were ground in a vibratory disc mill with a tungsten carbide set for 5 min, ensuring a resulting grain size of $<63 \mu \mathrm{m}$.

Petrographic analysis was done using a petrographic microscope with an attached point counting stage. Mineralogical composition was determined by counting 300 points per thin section, including pore space and cement. Points were counted equidistantly along a series of traverses across the thin section using the Gazzi-Dickinson method. Recorded components were monocrystalline quartz with straight extinction $(\mathrm{Qm})$, monocrystalline quartz with undulose extinction (Qmu), polycrystalline quartz (Qp), plagioclase feldspar (Plag), alkali feldspar (Afsp), lithic fragments (Lf), cement/pseudo matrix (Cem/PM) and pore space (Pore). Sorting and grain size classification was done by estimating the dominant, minimum and maximum grain-size fractions.

Most of the whole-rock geochemical analysis and preparation steps following grinding were carried out at the Geoscience Center at the Göttingen University. Major element analysis was done using X-ray fluorescence spectrometry (XRF) on fusion tablets. Sample powder was mixed with Spectromelt ${ }^{\circledR}$ A 12 (Merck) and LiF and fused in platinum crucibles. Melting and quenching of the glass tablets was done fully automatic with a Breitländer autofluxer ${ }^{\circledR}$ plus fusion machine. The tablets were then measured with a PANalytical AXIOS Advanced sequential X-ray fluorescence spectrometer. Major element data of some samples were determined at the Institute for Geosciences at the Mainz University following procedures described in Meinhold et al. (2007).

Solution inductively coupled plasma mass spectrometry (ICP-MS) was used for trace element geochemistry. Sample powder (100 $\pm 0.1 \mathrm{mg}$ per sample) was dissolved by acid digestion with $\mathrm{HF}-\mathrm{HNO}-\mathrm{HCl}$ prior to analysis, using a PicoTrace ${ }^{\circledR}$ acid sample digestion system. The samples underwent a pre-reaction with $2 \mathrm{ml} \mathrm{HNO} 3$ at $50{ }^{\circ} \mathrm{C}$ overnight. After cooling to room temperature, $3 \mathrm{ml} \mathrm{HF} \mathrm{(40 \% )} \mathrm{and} 3 \mathrm{ml} \mathrm{HClO} 4$ (70 to $72 \%$ ) were added and the samples heated to $150{ }^{\circ} \mathrm{C}$ for $8 \mathrm{~h}$ during the first pressure phase. In the subsequent evaporation phase, the crucibles were heated to $180^{\circ} \mathrm{C}$ and dried for $16 \mathrm{~h}$. Following cooling to room temperature, $10 \mathrm{ml} \mathrm{H} 2 \mathrm{O}$ (double de-ionised), $2 \mathrm{ml} \mathrm{HNO} 3$ and $0.5 \mathrm{ml} \mathrm{HCl}$ were added and the samples heated to $150{ }^{\circ} \mathrm{C}$ for $4 \mathrm{~h}$ during the second pressure phase. After final cooling, the samples were transferred into $100 \mathrm{ml}$ volumetric flasks and $200 \mu \mathrm{l}$ of an internal standard added. Samples, blanks and standards were analysed by a ThermoElectron VG PlasmaQuad 2 quadrupole ICP-MS. The Geological Survey of Japan standard JA-2 was used for calibration (supplementary material, Table S2). 
The set of 17 samples from Al-Ajmi et al. (2015) were analysed by the commercial laboratory Actlabs, Canada, for major and trace elements by ICP-MS. The Geological Survey of Japan standard JR-1 was used for calibration ((supplementary material, Table S2).

The Eu anomaly was calculated according to McLennan (1989):

$\mathrm{Eu} / \mathrm{Eu}^{*}=\mathrm{EuN} /(\mathrm{SmN} \times \mathrm{GdN}) 0.5$

where the subscript $\mathrm{N}$ denotes chondrite-normalised values.

Statistical analyses have been done with the software PAST, version 3.07 (Hammer et al. 2001). Ternary plots have been created using the GeoChemical Data toolkit (GCDkit) for R, version 2.13.2 (Janoušek et al. 2006).

Results

\section{Petrography}

Sample lithology was determined using point-counting data plotted in a QFL diagram (Fig. $3)$, petrographic parameters are presented in Table 2. Lithologies from both study areas are dominated by quartz arenites (Fig. 4 a, b), constituting over half of the analysed samples (50 $\%$ of Tabuk area samples, $67 \%$ of Wajid area samples). Subarkose is the second most numerous lithology (31\% of Tabuk area samples, $17 \%$ of Wajid area samples), with arkoses making up a minor fraction (19\% of Tabuk area samples, $11 \%$ of Wajid area samples). Pseudomatrix and cement are scarce to almost completely absent in most samples (Fig. 4c, d). Dominant grain size is affected by sampling bias and has been estimated in thin sections. Medium sand make up $77 \%$ of samples, fine sand $18 \%$ and coarse silt $5 \%$. Sorting is poor (Fig. $4 \mathrm{e}, \mathrm{f}$ ) to good with no discernible trends. Grains are subangular to rounded. Porosity ranges between approximately 5 and $20 \%$ and is highly variable within most formations (AlAjmi et al. 2014). Recorded minerals are predominantly quartz. Slightly less than half (46\%) of the quartz grains from the Wajid area have undulatory extinction, between $47 \%$ are $\mathrm{Qm}$ with straight extinction. Qp content ranges between 2 and $17 \%$. In contrast, the Juwayl Formation has significantly more Qm (66 \%) than Qmu (27\%). Sandstones from the Tabuk area have similar overall quartz composition, but the variability of the Qm/Qmu ratio within formations is higher than in samples from the Wajid area. Feldspar content is low in most samples. Where feldspar is present, alkali-feldspars are usually more abundant than plagioclase. Striking exceptions are one sample from the Juwayl Formation, which contains two generations of feldspar (Fig. 4c, d), and the Qusaiba and Sharawra members. Heavy minerals are dominated by zircon and rutile; some tourmaline and mica (muscovite, biotite and unidentified mica) were observed as well. Three samples have minor clinopyroxene and orthopyroxene. 


\section{Geochemistry}

Major and trace element concentrations of all analysed 44 samples are available as supplementary material (Table S1). Note that some samples from both literature and this study show $0 \%$ concentrations of some major elements ( $\mathrm{MgO}, \mathrm{MnO}, \mathrm{Na2O}, \mathrm{P} 2 \mathrm{O} 5$ and TiO2). In order to allow calculation of the $\mathrm{K} 2 \mathrm{O} / \mathrm{Na2O}$ ratio and the discriminant functions of Verma and Armstrong-Altrin (2013), which rely on log ratios, those samples had these respective element concentrations set to $0.0001 \%$. This allows the inclusion of those samples, but in the case of the $\mathrm{K} 2 \mathrm{O} / \mathrm{Na} 2 \mathrm{O}$ ratio versus $\mathrm{SiO} 2$ diagram slightly exaggerates the 'vertical spread' of the sample population. However, it has no influence on the behaviour of sample points near the field boundaries. Some samples revealed an intensive carbonatic cementation in thin section (Fig. 4c, d). These samples have been excluded from plots and calculations that include major elements.

Major elements

Major element concentrations have been normalised against Al2O3 since Al can be regarded as immobile during weathering, diagenesis and metamorphic processes (Cardenas et al. 1996; Bauluz et al. 2000). Correlation coefficients of major oxides with Al2O3 for both study areas are available as supplementary material (Table S3). Major element abundances reflect the lithologies and the high maturity of most analysed samples. SiO2 concentrations are high (71.43-99.8 \%) in most sandstones. SiO2/Al2O3 values are high in most samples (8.49-1108.89), but low in shale samples from the Qusaiba (5.69) and Sharawra members $(5.89 ; 6.02)$ as well as three micaceous sandstones of the Dibsiyah (6.84) and Jauf (5.89; 6.02) formations. $\mathrm{MgO}$ and $\mathrm{CaO}$ show no correlation with Al2O3 (Table S3) and concentrations are low in most samples, well below the average UCC and PAAS (Taylor and McLennan 1985, 2009; McLennan 2001). Three samples show high CaO/Al2O3 values (46.92), which is caused by strong calcitic cementation. Sandstones from the Wajid area are almost completely MgO-free, with one exception from the Qusaiba Member. Sandstones from the Tabuk area show low MgO concentrations. Elevated $\mathrm{MgO}$ abundances in samples from the Tawil Formation are due to intense dolomitic cementation. K2O concentrations are well below the UCC and PAAS averages in samples from the Wajid area and only slightly elevated in the Khusayyayn Formation. The Qusaiba Member has a K2O/Al2O3 value close to the UCC. In contrast, samples from the Jauf and Jubah formations show significantly higher $\mathrm{K} 2 \mathrm{O}$ concentrations. $\mathrm{K} 2 \mathrm{O}$ abundance in sandstones is mainly controlled by the presence of K-feldspar, K-mica and glauconite (Wedepohl 1978). Elevated K2O contents in the Jauf and Jubah formations reflect their modal composition, which is concordant with increased abundance of K-feldspar in thin sections. The high $\mathrm{K} 2 \mathrm{O}$ concentration in the Qusaiba Member (3.48\%) is probably caused by clay minerals in the matrix. Na2O is almost 
absent in most samples, but slightly more abundant in the Tabuk area. TiO2 concentrations are very low in sandstones from the Wajid area. Concentrations in the Tabuk area are higher with a significantly larger spread and are linked to biotite and rutile. The extremely high TiO2 content of sample AB-SA126 (2.33\%; Qasim Formation) is caused by rutile from a heavy mineral placer deposit. The sample has correspondingly increased concentrations of trace elements ( $\mathrm{Zr}$, Th, $\mathrm{Y}$ and REEs like $\mathrm{La}, \mathrm{Ce}, \mathrm{Sm}, \mathrm{Gd}$, Tb and Dy), which are indicative for other heavy minerals like zircon and monazite. TiO2 from Juwayl Formation samples comes from Ti-rich augite. In samples from the Wajid area, SiO2 shows a statistically significant negative correlation and $\mathrm{TiO} 2$ and $\mathrm{P} 2 \mathrm{O} 5$ a statistically significant positive correlation with Al2O3 (Table S3). MgO, Na2O, K2O and Fe2O3 correlate weakly with Al2O3, while MnO and $\mathrm{CaO}$ exhibit no correlation (Table S3). Samples from the Tabuk area display a statistically significant negative correlation of $\mathrm{Al} 2 \mathrm{O} 3$ with $\mathrm{SiO} 2$, statistically significant positive correlations with $\mathrm{K} 2 \mathrm{O}$ and $\mathrm{Fe} 2 \mathrm{O} 3$ as well as statistically not significant positive correlations with TiO2, Na2O and P2O5 (Table S3). There is no correlation of Al2O3 and MnO, MgO and $\mathrm{CaO}$ (Table S3). Statistically significant positive correlations of $\mathrm{K2O}, \mathrm{P} 2 \mathrm{O} 5, \mathrm{Fe} 2 \mathrm{O} 3$ and $\mathrm{TiO} 2$ with $\mathrm{Al} 2 \mathrm{O} 3$ indicate association with micaceous/clay minerals. $\mathrm{CaO}$ and $\mathrm{MgO}$ show no or statistically not significant correlations and originate mainly from carbonatic cement (Das et al. 2006). $\mathrm{Na} 2 \mathrm{O}$ and $\mathrm{K} 2 \mathrm{O}$ concentrations and their ratios (Na2O/K2O < 1) are consistent with the petrographic observation of alkali-feldspar as the dominant feldspar. Overall, the samples from the Wajid area show very similar major element abundances and are geochemically more mature (higher $\mathrm{SiO} 2$ concentration) than sandstones from the Tabuk area.

Trace elements

Selected trace element concentrations have been normalised against UCC values and are shown as spider plots as supplementary material (Fig. S1a, b). A correlation matrix of trace elements and some major oxides is also provided as supplementary material (Table S4; $n=$ 41).

Large-ion lithophile elements (LILE): $\mathrm{Rb}, \mathrm{Ba}, \mathrm{Sr}$ and $\mathrm{Cs}$

LILEs are relatively mobile and incompatible elements and are thus enriched in the UCC compared to the mantle. Mean LILE concentrations of samples from the Wajid area are well below the values for the UCC. Samples from the Dibsiyah and Sanamah formations are especially depleted in $\mathrm{Cs}, \mathrm{Rb}$ and $\mathrm{Ba}$. LILEs in samples from the Khusayyayn and Juwayl formations are less depleted than the Dibsiyah and Sanamah formations and show a large scatter. Mean LILE concentrations of samples from the Tabuk area are higher than those from the Wajid area, but show a larger scatter. The Jauf and Jubah formations as well as the Sharawra Member are an exception. They show very little scatter and have approximately 
UCC concentrations of LILEs. The rest of the samples from the Tabuk area have low LILE concentrations. $\mathrm{Cs}, \mathrm{Rb}$ and $\mathrm{Ba}$ show a statistically not significant positive correlation with Al2O3(Table S4). This may indicate phyllosilicates as a controlling factor of LILE concentrations (Etemad-Saeed et al. 2011). Variability and depletion of LILEs may be due to mobility during weathering, diagenesis and metamorphic processes (Wronkiewicz and Condie 1987).

High-field-strength elements: Th, U, Y, Zr, Hf, Nb and Ta

High-field-strength elements (HFSEs) are incompatible but immobile elements. They are enriched in felsic rather than mafic rocks (Bauluz et al. 2000). Due to their immobile nature, they are regarded as provenance indicators (Taylor and McLennan 1985). Zr and Hf behave similarly as is evidenced by their very high correlation coefficient $(r=1.00$; Table S4). $\mathrm{Zr}$ and $\mathrm{Hf}$ concentrations in rocks are mainly controlled by the heavy mineral zircon. This is supported by $\mathrm{Zr} / \mathrm{Hf}$ ratios mostly between 35 and 40 , similar to values reported for zircons by Murali et al. (1983). Furthermore, Zr shows statistically significant positive correlations with REEs ( $r=0.94$ ) suggesting that REEs are controlled by zircon abundances (Bauluz et al. 2000). The mean concentration of $\mathrm{Zr}$ in samples from the Wajid area is depleted compared to the average UCC in the Tabuk area; $Z r$ is enriched on average but shows a larger scatter than in the Wajid area. One outlier sample from the Qasim Formation is highly enriched in $\mathrm{Zr}$. This sample is probably from a heavy mineral placer deposit. Th and $\mathrm{U}$ concentrations are close to UCC values in both study areas but are slightly depleted in both Juwayl and Unayzah formations. Th and $U$ exhibit a statistically significant positive correlation between each other $(r=0.95)$ and also towards $\operatorname{Zr}(r=0.98$ and $r=0.91$, respectively), TiO2 ( $r=0.93$ and $r=0.86$, respectively) and REEs, which indicates that Th and $U$ concentrations are controlled by heavy mineral abundances. The mean $Y$ concentration is lower than the average UCC in the Wajid area. In the Tabuk area, the mean $Y$ abundance is comparable to the UCC but shows a larger scatter than the Wajid area. Controlling phases for $Y$ abundance are probably rutile and monazite rather than xenotime because of statistically significant positive correlations with $\mathrm{TiO} 2(r=0.90)$ and REEs $(r=0.93)$ but a low correlation coefficient with P2O5 ( $r=0.49)$. Nb has a statistically significant positive correlation with $\mathrm{Y}(r=0.94)$.

Transition trace elements: $\mathrm{Sc}, \mathrm{Cu}$ and $\mathrm{Ni}$

$\mathrm{Sc}$ and $\mathrm{Ni}$ are depleted compared to the UCC in both study areas. $\mathrm{Cu}$ concentrations are comparable to the UCC in most samples from the Wajid and Tabuk areas, with the exception of the Juwayl and Unayzah formations. No strong correlations between $\mathrm{Cu}$ and $\mathrm{Ni}$ and selected major elements have been observed. Sc correlates statistically not significant positive with Al2O3 $(r=0.72)$, TiO2 $(r=0.78), \mathrm{Zr}(r=0.70)$ and the (heavy) REEs $(r=0.79 ; r$ 
$=0.85$ for HREEs) (see Table S4). This may indicate phyllosilicates and heavy minerals as controlling factors for Sc concentrations (Etemad-Saeed et al. 2011).

Rare earth elements: La, Ce, Pr, Nd, Sm, Eu, Gd, Tb, Dy, Ho, Er and Yb

The average total rare earth elements (REE) concentration (LREE) in the Wajid area is 46.87 ppm, much lower than the average PAAS (183.93 ppm) and UCC (145.72 ppm) concentrations. This is excluding two outlier samples-one from the Qusaiba Member ( $\mathrm{REE}$ $=113.58 \mathrm{ppm}$ ) and one from the Dibsiyah Formation ( $\left.\sum R E E=367.19 \mathrm{ppm}\right)$. In contrast, the Khusayyayn Formation hosts a sample with very low REE concentrations ( $\Sigma$ REE $=15.88$ ppm). $\Sigma$ REE concentrations are higher in the Tabuk area, with an average concentration of $124.76 \mathrm{ppm}$. The average value is excluding one outlier sample from the Qasim Formation, which is extremely enriched in REEs ( $\sum R E E=1332.86 \mathrm{ppm}$ ). Two samples from the Tawil and Unayzah formations have very low total REE concentrations ( $\Sigma$ REE $=18.85 \mathrm{ppm}$; $\Sigma \mathrm{REE}=$ 27.17 ppm). REEs have been chondrite-normalised after McDonough and Sun (1995) and are provided as supplementary material (Fig. S1c, d). Cl-normalised REE patterns are similar to the PAAS and UCC with enriched LREEs, flat HREEs and a pronounced negative Eu anomaly. In contrast, samples from the Sharawra Member as well as Sarah, Zarqa and Saq formations show 'rising' HREE patterns. Like other lanthanides, Eu is an incompatible element, but is preferentially incorporated into plagioclase. As a result, the average UCC exhibits Eu depletion through fractionation effects, leading to an Eu anomaly of Eu/Eu* = 0.65. In samples from both study areas, the Eu anomaly is negative (Eu/Eu* $<1)$, but more pronounced in the Tabuk area. There the mean and median Eu/Eu* is lower than the PAAS and UCC, whereas in the Wajid area the Eu/Eu* values are slightly higher. The (La/Yb)C value, which describes the total slope of the Cl-normalised REE trend, is lower than the UCC in samples from the Khusayyayn and Juwayl formations, but higher in samples from the Dibsiyah and Sanamah formations. It is also much more variable in the Tabuk area, where no clear distinction between formations could be established. The LREE slope, represented by the $(\mathrm{La} / \mathrm{Sm}) \mathrm{c}$ value, is lower than or close to values of the UCC in most samples from the Wajid area. Only two samples from the Sanamah Formation show higher (La/Sm)c values than the UCC. This is mirrored in the Tabuk area. HREE patterns, as delineated by ( $\mathrm{Gd} / \mathrm{Yb}) \mathrm{c}$ values, are similar to the UCC in both study areas with no clearly discernible trends. A statistically not significant positive correlation between ( $\mathrm{La} / \mathrm{Sm}) \mathrm{C}$ and P2O5 indicates the LREE abundances to be at least partially controlled by phosphates. Other controlling factors could not be ascertained, as there are no correlations between $\mathrm{Eu} / \mathrm{Eu}{ }^{*},(\mathrm{La} / \mathrm{Yb}) \mathrm{c},(\mathrm{La} / \mathrm{Sm}) \mathrm{c}$, $(\mathrm{Gd} / \mathrm{Yb}) \mathrm{c}$ and any other major element or $\mathrm{Zr}$, Th and $\mathrm{U}$ (supplementary material, Table S5).

\section{Discussion}

\section{Source are weathering}


During transport and deposition, sediments undergo changes in their mineralogical and consequently in their major element composition, compared to their source rocks. For example, quartz, and thus $\mathrm{SiO} 2$, tend to become enriched. Feldspars on the other hand break down, leading to the removal of $\mathrm{Na2O}, \mathrm{K} 2 \mathrm{O}$ and $\mathrm{CaO}$ (Fedo et al. 1995). The (geochemical) composition of sedimentary rocks is controlled by a complex interplay of various factors, like provenance, weathering, fractionation, sorting and diagenesis, which are dependent on aspects such as tectonic setting and climate (Bhatia 1983; Johnsson 1993). At the extreme end of this process stand highly mature quartz arenites. They are the result of intensive chemical weathering, reworking and/or sedimentary recycling. Reworking in this case refers to the re-mobilisation of sediment during deposition, for instance by currents. Recycling means erosion of an older sedimentary succession. Weathering and climate have a profound impact on the composition and maturity of siliciclastic sediments (Chandler 1988). The amount and influence of source area weathering has to be taken into account in order to correctly interpret the provenance of Saudi Arabian Palaeozoic sandstones.

A vast variety of different chemical weathering indices have been used to estimate and quantify weathering of rocks (Fedo et al. 1995; Duzgoren-Aydin et al. 2002). Among those, the chemical index of alteration (CIA) of Nesbitt and Young (1982) is the most widely accepted und utilised tool to describe weathering in siliciclastic sediments (Bahlburg and Dobrzinski 2011). It is a measure of Al2O3 versus labile oxides and defined as

$\mathrm{ClA}=100 \times \mathrm{Al} 2 \mathrm{O} 3 /(\mathrm{Al} 2 \mathrm{O} 3+\mathrm{CaO} *+\mathrm{Na} 2 \mathrm{O}+\mathrm{K} 2 \mathrm{O})$

where $\mathrm{CaO}^{*}$ represents the $\mathrm{Ca}$ of silicates only. Samples with carbonatic matrix have not been taken into account. $\mathrm{CaO}$ was low in all considered samples. Therefore, $\mathrm{CaO}^{*}$ was regarded equal to $\mathrm{CaO}$. All element oxides are in molar proportions. Lower values $(<50)$ indicate low weathering; higher values $(>70)$ indicate intense weathering. During feldspar weathering $\mathrm{Na}+, \mathrm{K}+$ and $\mathrm{Ca} 2+$ are mobilised and removed from the system by soil solutions, while the immobile Al2O3 remains (Fedo et al. 1995). Consequently, the CIA is a measure of feldspar alteration into clay minerals (Fedo et al. 1995; Akarish and El-Gohary 2008). Problems may occur when transport and sorting effects lead to fractionation of grain sizes, which tends to concentrate Al-rich clays in the mud fractions and feldspars and quartz in the sand fraction (Nesbitt et al. 1996). Recycled sediments may have undergone several fractionation and sorting events. This can potentially lead to CIA values that are not representative for the weathering processes and climate in the source area, but may reflect weathering in an older sedimentary basin (Huntsman-Mapila et al. 2009).

Higher $\mathrm{ClA}$ values for samples from the Saq, Qasim, Zarqa and Sarah formations from the Tabuk area and the Dibsiyah and Sanamah formations from the Wajid area indicate moderate to intense weathering and/or sediment recycling in the source area 
(supplementary material, Table S6). The relatively low $\mathrm{CIA}$ of the remaining formations (Table S6) would suggest low weathering conditions and/or mixing of fresh, unweathered material with recycled sediments.

A second, similar chemical weathering index is the plagioclase index of alteration (PIA) of Fedo et al. (1995). It is defined as

$\mathrm{PIA}=100 \times \mathrm{Al} 2 \mathrm{O} 3-\mathrm{K} 2 \mathrm{O} /(\mathrm{Al} 2 \mathrm{O} 3+\mathrm{CaO} *+\mathrm{Na} 2 \mathrm{O}-\mathrm{K} 2 \mathrm{O})$

In molar proportions and where $\mathrm{CaO}^{*}$ represents the $\mathrm{Ca}$ of silicates only. $\mathrm{CaO}$ was considered to be equal to $\mathrm{CaO}^{*}$.

$\mathrm{CIA}$ and PIA have a statistically significant positive correlation $(r=0.84 ; n=39)$ and have mostly comparable values (Table S6). Noticeable differences in between CIA and PIA occur in the Qusaiba and Sharawra members as well as the Tawil, Jauf, Jubah and Unayzah formations. The exact cause could not be determined with the current dataset.

A third way to quantify source area weathering is the mineralogical maturity index (MI), which is expressed as the ratio of quartz to quartz + feldspar + lithic fragments (Pettijohn 1954). Mean values in the Wajid area are uniformly high, indicating a very high mineralogical maturity (Table S6). The majority of the Tabuk area samples show high to very high mineralogical maturity as well (Table S6). Very high MI values are explained by (meta-) sedimentary recycling by Bhatia and Crook (1986). MI values for the present dataset do correlate with neither the $\mathrm{CIA}(r=0.34 ; n=39)$ nor the PIA $(r=-0.05 ; n=39)$. This suggests that the controlling factors for both the $\mathrm{CIA}$ and PIA are not found in the framework grains, but in the matrix and cement of the sandstones.

A ternary diagram of $\mathrm{Al} 2 \mathrm{O} 3, \mathrm{CaO}^{*}+\mathrm{Na} 2 \mathrm{O}$ and $\mathrm{K} 2 \mathrm{O}(\mathrm{A}-\mathrm{CN}-\mathrm{K})$ can be used to determine weathering trends (Nesbitt and Young 1984). Samples from the Wajid area uniformly plot very close to the $\mathrm{A}-\mathrm{CN}$ side of the triangle, leaning more towards the $\mathrm{A}$ apex (supplementary material, Fig. S2b). Results from this study are in accordance with literature data from Hussain (2001), Babalola et al. (2003) and Hussain (2007) (grey area in Fig. S2 represents range of literature data). This is a surprising observation, since plagioclase breaks down much more easily than K-feldspar. Consequentially, one would expect highly weathered and mature sandstones to plot near the $A-K$ line and the $A$ apex. Samples from the Tabuk area show a much wider spread in the A-CN-K diagram than those from the Wajid area (supplementary material, Fig. S2a). A lot of the samples, especially from the Jauf and Jubah formations, plot towards the A-K line of the diagram. A possible explanation could be a change in the weathering regime, a change in provenance or both. This distributional pattern may then have been amplified by sorting effects during transport, since the sampling points for the Jauf and Jubah formations are significantly farther away from the potential source areas than the other formations (Fig. 1c). 
The most likely reason for the unexpectedly low $\mathrm{CIA}$ and PIA values and sample point distribution in the A-CN-K diagram are sorting effects. Nesbitt and Young (1982) looked only at very fine grained sediments (lutites), which are enriched in clay minerals and thus ideally suited to preserve the weathering signal determined with both the CIA and PIA. Coarser material, like the sandstones from this study, might be deposited without the accompanying clay fraction. This effectively leads to $\mathrm{Al} 2 \mathrm{O} 3$ depletion as the clay minerals are washed out and deposited further downstream (Nesbitt et al. 1996). The CIA and PIA of the remaining coarser fraction are consequently lower and no longer directly reflect weathering processes in the source area.

\section{Sedimentary recycling}

Apart from the aforementioned problems, one fundamental flaw with all three weathering indices ( $\mathrm{CIA}, \mathrm{PIA}$ and $\mathrm{MI}$ ) as well as the $\mathrm{A}-\mathrm{CN}-\mathrm{K}$ ternary diagram remains: they fail to distinguish strong weathering from sedimentary recycling. Petrographical and textural maturity of the studied samples suggests sediment recycling. Hussain et al. (2004) consider, among several Neoproterozoic terranes, the 'infra-Cambrian' Ghabar Group in Yemen to be a source for recycled sandstones of the Wajid area. McLennan et al. (1993) used ratios of $\mathrm{Th} / \mathrm{Sc}$ versus $\mathrm{Zr} / \mathrm{Sc}$ to identify sedimentary recycling trends in modern turbidite sands. Sc has been used to normalise for its uniform abundance in most minerals. The Th/Sc ratio is mainly governed by compositional variances in the source rock, whereas the $\mathrm{Zr} / \mathrm{Sc}$ ratio is related to the zircon content of siliciclastics. Recycling of clastic sediments usually leads to an increase in maturity and zircon enrichment and thus to increased $\mathrm{Zr} / \mathrm{Sc}$ ratios (McLennan et al. 1993). In the results of this study, no overall recycling trend could be observed. Most samples plot together in a point cloud, regardless of stratigraphic position (Fig. 5a). For a clear recycling signal, one would expect to have a much flatter trend line and older samples to have overall lower $\mathrm{Zr} / \mathrm{Sc}$ ratios than younger ones. This is an argument against an Early Palaeozoic source for later Palaeozoic sediments and intensive, continuous recycling of older sandstones. Subordinate recycling trends within single stratigraphic units could not be proven either. Each formation has been checked for recycling trends (plots not shown in this paper), without correlations between $\mathrm{Zr} / \mathrm{Sc}$ ratio and stratigraphic position. Samples from the Khusayyayn and Juwayl formations have comparatively low Th/Sc and $\mathrm{Zr} / \mathrm{Sc}$ ratios, compared to the Dibsiyah and Sanamah formations (Fig. 5a). Corresponding samples from the Tabuk area do not show this trend. One possible explanation is an influx of fresh sediments-possibly from the nearby basement rocks of the ANS-in the Wajid area, which did not reach the northern Arabian basin. A second possibility is simply regional variation. Both explanations hint to a change in the provenance of the Khusayyayn and Juwayl formations.

Considering the Arabian Shield as the main source for Palaeozoic sandstones (Babalola 1999; Hussain 2001; Hussain et al. 2004; Al-Harbi and Khan 2005, 2008, 2011; Wanas and Abdel-Maguid 2006; Knox et al. 2007) leads to further difficulties in interpreting the Th/Sc 
versus $\mathrm{Zr} / \mathrm{Sc}$ diagram. In Fig. 5b, some typical basement rocks of the Arabian Shield (from Jackson et al. 1984; Stuckless et al. 1985, 1986; Jackson and Douche 1986; Leo 1986; Ramsay et al. 1986; and own samples) are plotted together with Palaeozoic sediments. The selected basement samples represent potential source rocks for the Palaeozoic sandstones and cover a wide area of the Arabian Shield. They can thus be considered 'end members' of a hypothetical mixing process. The samples show a wide spread across the diagram. Some points plot in the same position as the sediment samples. This is true even for high $\mathrm{Zr} / \mathrm{Sc}$ and moderate Th/Sc values, which are interpreted by McLennan et al. (1993) to indicate sedimentary recycling. Because of the wide spread of basement samples in the diagram, it is possible to explain high $\mathrm{Zr} / \mathrm{Sc}$ values of sediments not only by sedimentary recycling but also with mixing of different basement rocks. Contrary to the suggestion of McLennan et al. (1993), the Zr/Sc ratios of Saudi Arabian Palaeozoic sandstones seem not only to be controlled by sedimentary processes but also have significant dependence on the source rocks as well.

Trace element geochemistry, especially $\mathrm{Th}, \mathrm{Zr}$ and Sc concentrations, of Saudi Arabian Palaeozoic sandstones show no evidence of a significant input from a recycled sedimentary source. Instead, variances in those element abundances can be explained by mixing of different magmatic source rocks from the ANS. The mineralogical maturity of the analysed samples is very high, which has been attributed to be the result of sedimentary recycling by Bhatia and Crook (1986). Yet it can also be explained by intensive weathering and reworking. Modal composition is not only dependent on provenance but also modified by weathering, fractionation, sorting, chemical alteration as well as diagenetic effects (Weltje 2004; Weltje and von Eynatten 2004) and thus unable to differentiate recycling from reworking. Although intensive source area weathering is not indicated by both the CIA and PIA, it cannot be refuted either.

Evidence for the presence of first-cycle quartz arenites on the northern Gondwana margin were presented by Avigad et al. (2005). Detrital zircon ages from Cambrian sandstones from the Elat area of southern Israel reveal only a short time lag between consolidation of the magmatic source and deposition of detritus. This time lag has not been long enough to allow sedimentary recycling. Hence, the maturity of those sandstones is a result of intensive source area weathering coupled with low sedimentation rates (Avigad et al. 2005). Further similar detrital zircon ages are also reported from Cambrian-Ordovician sandstones from Israel and Jordan (Kolodner et al. 2006). Adjacent to the northern ANS and south of the Elat, Early Palaeozoic sandstones from the eastern Sinai Peninsula have been interpreted to be first-cycle sediments as well (Akarish and El-Gohary 2008).

In Saudi Arabia, Babalola (1999) concluded a first-cycle provenance from intermediate to felsic source terranes in Yemen for sandstones from the Wajid area, utilising petrographical and geochemical methods as well as heavy mineral analysis. Wanas and Abdel-Maguid (2006) arrived at the same results for Lower Palaeozoic sediments from the Wajid area. AlHarbi and Khan (2005) argued that reworking during deposition, not recycling, is mainly responsible for the maturity of quartz arenites of the Unayzah Formation. Similar, albeit not identical conclusions are presented by Al-Harbi and Khan $(2008,2011)$ for the Tawil and 
Sarah formations of the Tabuk area. They identify, apart from granitic and metasedimentary rocks, polycyclic sediments as part of the source for these units, but also mention extensive reworking. Their conclusions fit well to the dataset presented in this paper. In contrast, by studying heavy mineral assemblages of sandstone from the Wajid area, Hussain et al. (2004) infer a mix of Neoproterozoic basement and 'infra-Cambrian' sediments from Yemen as source for Palaeozoic sediments in the Wajid area. They completely disregard the exposed terranes of the ANS to the north and west as significant sources.

It is evident that the question of sedimentary recycling is far from solved and that further studies are required. Considering the results of this study, the most likely explanation for the high mineralogical maturity of the samples and the lack of apparent recycling trends in the geochemical data seems to be a mixture of compositional variation of source rocks and reworking during deposition.

\section{Tectonic setting}

The petrographical and major element composition of sedimentary rocks can give some clues not only about reworking and weathering conditions but also on the tectonic setting of their depositional basin. Geochemical discrimination diagrams have been used for decades to infer the tectonic setting of sedimentary basin (e.g. Bhatia 1983; Bhatia and Crook 1986; Roser and Korsch 1986; Roser and Korsch 1988; Verma and Armstrong-Altrin 2013). There is a strong grain size control on sediment composition, which limits the usefulness of whole-rock geochemical analysis in sedimentary provenance studies (von Eynatten et al. 2012). Armstrong-Altrin and Verma (2005) evaluated six common tectonic setting discrimination diagrams proposed by Bhatia (1983) and Roser and Korsch (1986). They compiled an extensive database of geochemical data of Miocene to recent sands and sandstones from known tectonic settings. This dataset was then used to test the six discrimination diagrams. Success rates varied greatly but were better for the diagram of Roser and Korsch (1986), which managed to correctly discriminate 32 to $62 \%$ of the samples. The major element plots and discriminant function diagram of Bhatia (1983) fared even worse, successfully discriminating only 0 to $58 \%$ of the samples. It is noteworthy that most of the discrimination fields in the plots of Bhatia (1983) had a success rate of $25 \%$ or lower and are therefore not further considered in this study. Although the diagram of Roser and Korsch (1986) worked better, the maximum success rate of $62 \%$ is still unsatisfactory and lower than that for the petrographical 'Dickinson model'. Roser and Korsch (1986) used the $\mathrm{K} 2 \mathrm{O} / \mathrm{Na} 2 \mathrm{O}$ ratio versus $\mathrm{SiO} 2$ concentration in order to discern three different tectonic settings. Samples from both study areas have $\mathrm{SiO} 2, \mathrm{~K} 2 \mathrm{O}$ and $\mathrm{Na} 2 \mathrm{O}$ concentrations typical for sediments deposited on a passive margin (Fig. 6a, b). This is in accordance with literature data (grey area in Fig. 6a, b) and the established tectonic model of the Arabian Peninsula (Sharland et al. 2001). A passive margin or intracratonic setting can also be inferred from the high petrographical and geochemical maturity of the samples (Schwab 1978; Weltje et al. 1998). 
Verma and Armstrong-Altrin (2013) proposed new discrimination function-based diagrams to discern the tectonic setting of siliciclastic sediments, utilising major elements ( $\mathrm{SiO} 2, \mathrm{TiO} 2$, Al2O3, Fe2O3, $\mathrm{MnO}, \mathrm{MgO}, \mathrm{CaO}, \mathrm{Na2O}, \mathrm{K} 2 \mathrm{O}$ and P2O5). They introduced two sets of diagrams, optimised for either low-silica (35-63\% SiO2) or high-silica rocks (63-95\% SiO2). Both sets were successfully tested on Neogene-Quaternary as well as Precambrian sediments (success rates of 75-100\%) (Verma and Armstrong-Altrin 2013; Armstrong-Altrin 2015). Three different tectonic settings were considered: Continental and ocean island arcs ('Arc'-field), continental collision ('Col'-field) and continental rifting leading to the development of passive margins and intracratonic basins ('Rift'-field) (Fig. 6c, d). Samples with elevated $\mathrm{CaO}$ due to calcitic cementation were not considered. Most of the samples fall into the rift-field, which fits well to the passive margin setting suggested by the diagrams of Roser and Korsch (1986). Yet the sample population shows a larger spread. Out of 21 sandstone samples from the Tabuk area, 6 plot close to the border of and within the collisional field. Unlike samples from the Sarah and Zarqa formations from this study, Sarah samples from Al-Harbi and Khan (2011) plot entirely in the collisional field. Sandstones from the Wajid area cluster more closely together in the rift-field, which is largely in accordance with literature data. Significant discrepancies exist between the presented dataset and the samples analysed by ActLabs (grey symbols, Fig. 6d). Those samples concentrate around the rift-collisional field boundary and in the collisional field. Although the majority of analysed samples are identified as of rift-/passive margin/intracratonic basin setting, there is a larger spread of the data compared to the diagram of Roser and Korsch (1986). The likely explanation is an increased sensitivity to source rock composition and provenance. The signal from sediments deposited in a different tectonic setting than that of their source rocks may be overprinted by the source signal ('provenance signal') in some cases (Verma and Armstrong-Altrin 2013). While the intra-cratonic setting of the Arabian Platform is prevalent, some samples display a collisional signal, linked to the final stages of the PanAfrican Orogeny in the late Neoproterozoic. Fresh material from the Arabian Shield might have been able to carry this tectonic signature into the basin and preserve it. This theory explains the collisional setting of Sarah samples from Al-Harbi and Khan (2011). Although these authors inferred a predominantly sedimentary to metasedimentary source from petrographical observations and the diagrams of Roser and Korsch $(1986,1988)$, they also mention a possible granitic source. The new discrimination diagram of Verma and Armstrong-Altrin (2013) is arguably better suited to reflect the initial tectonic source signal over weathering and recycling. This is further confirmed by samples from the Sanamah and Juwayl formations, which also plot in the collisional field (Fig. 6d, grey symbols). During glacial periods, Neoproterozoic basement of the Pan-African Orogen apparently constituted a significant source for Palaeozoic sandstones.

\section{Provenance}


Not only the tectonic setting of the sedimentary basin but also the type of source rocks supplying the detritus can be deduced by studying the petrography as well as major and trace element composition of sediments.

Dickinson and Suczek (1979) and Dickinson et al. (1983) used detrital framework modes of sandstone suites to deduce provenance. Ternary diagrams of quartz (Q), feldspar (F) and lithic fragments ( $L$ ) as well as monocrystalline quartz $(\mathrm{Qm})$, feldspar $(F)$ and lithic fragments (including polycrystalline quartz) (Lt) are subdivided into tectonic provenance fields. When dealing with quartz-rich sandstones, the QmFLt diagram is better suited to differentiate recycled orogenic provenance settings, since chert grains and quartzose lithic fragments are indistinguishable in the QFL plot. As the sedimentary suites of both study areas are dominated by quartz-rich sediments, the results from the QmFLt diagram have been chosen in this study (available as supplementary material, Fig. S3). Samples from the Tabuk area plot mostly in the continental block fields. Only six samples can be interpreted to be of quartzose recycled provenance. A craton interior and quartzose recycled provenance seems to be prevalent in samples from the Saq and Qasim formations, while younger sediments fall also into the transitional continental and even the basement uplift fields (Fig. S3a). A similar distribution pattern can be observed for samples from the Wajid area (Fig. S3b). A transition from an intra-cratonic setting to a back-arc in northern Arabia towards the end of the Devonian (Fig. 2) could not be identified from detrital mode data. Problems with quartz-rich sands derived from craton interior and recycled orogenic provenance were already recognised by Dickinson et al. (1983). The 'Dickinson model' has been reviewed and challenged in recent years (e.g. Weltje 2002; Weltje 2004; Weltje and von Eynatten 2004; Weltje 2006). QFL and QmFLt plots have a success rate of $75 \%$ and do not deal adequately with sands of mixed provenance (Weltje 2006). Some of the main issues are that detrital modes are not insensitive to fractionation (Weltje 2004) and they are further modified during sediment generation and dispersal by weathering, abrasion, sorting, chemical alteration and after burial by diagenetic effects (Weltje and von Eynatten 2004), which in turn are, at least partly, independent from provenance and tectonic setting. Results obtained from the 'Dickinson model' must be interpreted with caution and should be supplemented by other techniques (von Eynatten and Dunkl 2012).

Roser and Korsch (1988) proposed a diagram to determine sedimentary provenance and source rock composition. It differentiates four source rock types: felsic igneous (acidic plutonic and volcanic detritus), intermediate igneous (andesitic detritus), mafic igneous (basaltic and subordinate andesitic detritus) and quartzose sedimentary (recycled detritus). The first three groups are interpreted as first-cycle sources, while the quartzose sedimentary is polycyclic. Samples with intensive carbonate cementation have not been considered in the plot. All analysed samples fall firmly in the quartzose sedimentary field (Fig. 7a, b). This suggests either a significant contribution from recycled sediments or intensive reworking and weathering. The plotting range of samples in the quartzose sedimentary field is much tighter for samples from the Wajid area, while samples from the Tabuk area show a larger spread. This may again be due to regional variation and greater differences in depositional facies in the northern study area. 
Trace elements are arguably better suited to determine the source rocks of a sedimentary suite (McLennan et al. 1993; Bracciali et al. 2007). A ternary plot of Ni-V-Th*10 can be used to discern between three source rock 'end-members': ultramafic, mafic and felsic rocks (Bracciali et al. 2007). Unsurprisingly, all samples from both study areas have felsic source rock signatures (Fig. 7c, d). A noticeable stratigraphic grouping can be seen in samples from the Wajid area. Samples from the Dibsiyah and Sanamah formations tend to cluster more towards the idealised felsic composition. Samples from the Khusayyayn and Juwayl formations are more spread out and seem to have more mafic input (Fig. 7d). This trend is not apparent in the Tabuk area (Fig. 7c). Literature data (from Hussain 2001; Al-Harbi and Khan 2011) show a significant spread. Especially, data from the Sarah Formation indicate a significant mafic and ultramafic input. This again points to a relic signal from the Neoproterozoic Arabian Shield and fits their collisional provenance in the diagram of Verma and Armstrong-Altrin (2013).

McLennan et al. (1993) published several geochemical criteria using trace elements, among them Eu/Eu*, Th/Sc and Th/U which are widely used in many studies (Bauluz et al. 2000; Cullers and Podkovyrov 2002; Cingolani et al. 2003; Young et al. 2004; Das et al. 2006; Etemad-Saeed et al. 2011) to discern the provenance of sediments. They can be used to discern the following provenance types: old upper continental crust (OUC), recycled sedimentary (RS), young undifferentiated arc (YUA), young differentiated arc (YDA) and 'exotic components'. YUA and YDA provenance types correspond to the arc setting, but cannot differentiate further between continental and island arcs. Likewise the OUC and RS provenance types represent the combined collisional, intracratonic and passive margin settings, without differentiating them. 'Exotic components' are any provenance signals at odds with the predominant setting, for example, sediments derived from allochthonous terranes. When plotted in a Th/U versus Th diagram (supplementary material, Fig. S4), some samples show a distinct separation. Most of the samples from the Tabuk area and those from the Dibsiyah Formation of the Wajid area have Th/U ratios similar or higher than the average UCC. This is further evidence for an intracratonic setting. In contrast, the Sanamah and Khusayyayn formations from the Wajid area show a noticeable grouping significantly below UCC values, with $U$ and Th concentrations typical for a 'depleted mantle source'. While high $T h / U$ values point to either an OUC source or sedimentary recycling and reworking, low Th/U values are indicative for (unweathered) material derived from volcanic arcs. Also, characteristic for arc-sourced sediments are Th concentrations lower than those of Sc. Whereas the Sanamah Formation exhibits Th and Sc concentrations typical for intracratonic sediments, Th/Sc values in the Khusayyayn Formation are predominantly around or lower than one (figure not shown). Possible sources for this detritus are Neoproterozoic juvenile arc terranes that form the core of the ANS (Johnson et al. 2011), which is in accordance with an increased mafic input inferred by $\mathrm{Ni}, \mathrm{V}$ and Th abundances. A similar distribution in sandstones from the Tabuk area has not been observed (Fig. S4a). As discussed above, an influx of fresh material, possibly coupled with some minor regional variations in provenance seems likely for the Khusayyayn Formation. Evidence for that are a lower $\mathrm{CIA}, \mathrm{Th} / \mathrm{Sc}, \mathrm{Zr} / \mathrm{Sc}$ and a marginally lower $\mathrm{MI}$ than in other samples from the Wajid 
area. This influx was confined to the Wajid area and did not reach the sampling sites for the Tawil, Jauf and Jubah formations.

\section{Chemostratigraphy}

From the results of this study as well as from literature data, we tentatively identified possible geochemical markers from some discrimination diagrams. The Khusayyayn and Juwayl formations are characterised by low Th/Sc and $\mathrm{Zr} / \mathrm{Sc}$ values (Fig. $5 \mathrm{a}$ ) as well as a slightly higher (ultra-) mafic input (Fig. 7c, d) compared to other formations. Literature data from the Sarah Formation (from Al-Harbi and Khan 2011) display a distinct mafic signal that clearly separates them from other samples from the Tabuk area. The same separation can also be seen in the distinct collisional setting for those samples in the tectonic discrimination diagram of Verma and Armstrong-Altrin (2013) (grey area, Fig. 6c).

While the aforementioned criteria may be used as geochemical markers, the 'manual' selection of elements or ratios is too arbitrary, necessitating a statistical approach. One such approach is cluster analysis, which is a multivariate analysis tool to statistically organise large datasets in significant groups or 'clusters' of increasing similarity. The following variables were included in the cluster analysis: the concentrations of LILEs, HFSEs, TTEs, TiO2, Al2O3 as well as the ratios of $\Sigma$ LREE/ $\mathrm{HHREE}$, Eu/Eu* and the CIA value. As a consequence of the inclusion of major element data, samples with extensive cementation were excluded. After determining and removing potential outliers with the 'single linkage' method, a cluster analysis was performed using 'Ward's method'. The resulting cluster dendrogram can be accessed as supplementary material (Fig. S5). The Wajid area was divided into two parts. Samples from the Dibsiyah and Sanamah formations tend to cluster in the left side of the dendrogram, while samples from the Khusayyayn and Juwayl formations cluster in the centre. Samples from the Tabuk area do not display any significant clustering. Although some overlap exists, this grouping points to a higher degree of homogeneity between Wajid area samples and a clear distinction from the Tabuk area. The clustering pattern is also in accordance with the observations from the $\mathrm{Th} / \mathrm{Sc}$ versus $\mathrm{Zr} / \mathrm{Sc}$ plot (Fig. 5a).

Another useful tool of multivariate analysis of large datasets is principal component analysis (PCA). The sample range and considered variables for the PCA were the same as for the cluster analysis. A correlation matrix was used, since the dataset contains different units of measurement and dimensionless ratios. Results of the PCA are plotted as biplot in Fig. 8a, b. The plot shows that $\mathrm{Y}, \mathrm{Nb}$ and Lu show a strong correlation and moderate influence on PC 1 and therefore the total variance. PC 2 is mainly controlled by Eu/Eu*, with minor contributions by the concentration of Ta as well as the CIA and $\Sigma$ LREE/LHREE, which show a statistically not significant correlation with $\mathrm{Ta}$ and $\mathrm{Eu} / \mathrm{Eu}^{*}$. The remainder of the variables are aligned between the axes and do not exert much control on PC 1 and PC 2. Therefore, the variance of the dataset is mostly controlled by the $\mathrm{Y}, \mathrm{Nb}$ and Lu content of the samples, 
with Eu/Eu*, Ta concentration, $\mathrm{CIA}$ and $\Sigma \mathrm{LREE} / \Sigma \mathrm{HREE}$ having only minor influence on the total variance.

$\mathrm{Nb}$, Ta and $\mathrm{Y}$ abundances are primarily controlled by heavy minerals, especially rutile and monazite. Rutile however exerts only minor control on the total variance, as can be inferred from the TiO2 concentrations, which do not correlate with either PC 1 or PC 2. This noncorrelation is also apparent with $\mathrm{Zr}$ and $\mathrm{Hf}$ concentrations, suggesting zircon abundances do not vary much throughout both successions. Likewise, clay minerals do not vary much as well, as is demonstrated by the non-correlation of $\mathrm{Al} 2 \mathrm{O} 3$ with the principal components one and two. The sample distribution in the scatter plots shows a clear distinction between the two study areas. The Wajid area samples cluster closely together (grey areas, Fig. 8b) and are clearly distinct from the Tabuk samples. A subordinate trend within the samples from the Wajid area separates the Dibsiyah and Sanamah formations (hollow circles, Fig. 8b) from the Khusayyayn and Juwayl formations (filled circles, Fig. 8b). Both the CIA and Eu/Eu* are linked to the abundance of plagioclase. They are thus strongly influenced by weathering and susceptible to sorting effects. Whilst a clear separation is visible in samples from the Wajid area, it may be strongly dependant on facies variability rather than representing changes in provenance or climate. Due to the small sample size, this dataset can only be considered a pilot study. To identify and develop robust geochemical markers a larger, statistically more significant database needs to be established.

\section{Conclusions}

Palaeozoic sandstones of Saudi Arabia are dominated by quartz arenites. They have a high mineralogical and textural maturity, which probably stems from intensive weathering and reworking during deposition. The igneous basement rocks of the Arabian Shield could not be unequivocally confirmed or refuted as the main source for Saudi Arabian Palaeozoic sandstones, but are very likely a large contributor. The issue of sedimentary recycling and its influence on the provenance could not be solved by this dataset. The tectonic discrimination diagrams of Dickinson et al. (1983) as well as Roser and Korsch $(1986,1988)$ unequivocally confirm passive margin/intracratonic setting. These results are in accordance with literature data and the established evolutionary model for the Arabian Peninsula. New discrimination diagrams proposed by Verma and Armstrong-Altrin (2013) also confirm the passive margin/intracratonic setting, although some samples show collisional characteristics. These are interpreted as relictic signals from the last stages of the amalgamation of Gondwana, which were carried over by glaciogenic sediments. An influx of fresh basement material into Wajid area during the Late Palaeozoic could be proven by $\mathrm{Th}, \mathrm{Zr}$ and Sc concentrations as well as cluster analysis. This influx is not recorded from the sampling sites in the Tabuk area. Geochemical analysis revealed some potential markers for the correlation of barren units, like variances in $\mathrm{Th} / \mathrm{Sc}$ and $\mathrm{Zr} / \mathrm{Sc}$. Multivariate cluster and principal component analyses allowed to differentiate between the two study areas as well as to separate Early and Late Palaeozoic formations in the Wajid area. While the 
geochemical approach has shown clear potential, a much larger dataset is needed to clearly characterise and correlate individual formations.

\section{Acknowledgments}

This study has been enabled by the logistical support of the Gesellschaft für Internationale Zusammenarbeit (GIZ) and DornierConsulting (DCo) in Riyadh. We thank Randolf Rausch (Riyadh) and the entire GIZ/DCo staff for their assistance and support during the 2013 field campaign and their interest in this study. We further want to thank Irina Ottenbacher (Göttingen) for her invaluable help during sample preparation. Nora Groschopf (Mainz) and Gerald Hartmann (Göttingen) are thanked for XRF analysis and Klaus Simon (Göttingen) for ICP-MS analysis. Sample analysis has been partially financed by the German Research Foundation (DFG grant ME 3882/4-1). We furthermore want to thank John S. ArmstrongAltrin (Mexico City) and an anonymous reviewer for their helpful suggestions and comments, which greatly helped to improve the manuscript.

\section{Supplementary material}

The online version of this article (doi:xxxxxxxxxxxxxx) contains supplementary material, which is available to authorized users.

\section{References}

Akarish AIM, El-Gohary AM (2008) Petrography and geochemistry of lower Paleozoic sandstones, East Sinai, Egypt: implications for provenance and tectonic setting. J Afr Earth Sci 52:43-54

Al-Ajmi HF (2013) Sedimentology, stratigraphy and reservoir quality of the Paleozoic Wajid Sandstone in SW Saudi Arabia. Technische Universität Darmstadt, Germany, Dissertation

Al-Ajmi HF, Hinderer M, Keller M, Rausch R (2008) New insights into the facies distribution of the Wajid Sandstone in its western outcrop area and implication on reservoir properties. The 3rd international conference on water resources and arid environments and the 1st Arab water forum, Riyadh, Saudi Arabia

Al-Ajmi HF, Hinderer M, Rausch R, Hornung J, Bassis A, Keller M, Schüth C (2014) Matrix versus fracture permeability in a regional sandstone aquifer (Wajid Sandstone, SW Saudi Arabia). Grundwasser 19:151-157 
Al-Ajmi HF, Keller M, Hinderer M, Filomena CM (2015) Lithofacies, depositional environments and stratigraphic architecture of the Wajid Group outcrops in southern Saudi Arabia. GeoArabia 20:49-94

Al-Ghazi A (2007) New evidence for the Early Devonian age of the Jauf Formation in northern Saudi Arabia. Revue Micropaléontol 50:59-72

Al-Hajri SA, Filatoff J, Wender LE, Norton AK (1999) Stratigraphy and operational palynology of the Devonian System in Saudi Arabia. GeoArabia 4:53-68

Al-Hajri S, Paris F (1998) Age and palaeoenvironment of the Sharawra Member (Silurian of north-western Saudi Arabia). Geobios 31:3-12

Al-Harbi OA, Khan MM (2005) Mineralogy and geochemistry of Unayzah Formation, central Saudi Arabia: implications for provenance interpretation. J King Saud Univ Sci 18:35-49

Al-Harbi OA, Khan MM (2008) Provenance, diagenesis, tectonic setting and geochemistry of Tawil Sandstone (Lower Devonian) in central Saudi Arabia. J Asian Earth Sci 33:278-287

Al-Harbi OA, Khan MM (2011) Source and origin of glacial paleovalley fill sediments (Upper Ordovician) of Sarah Formation in central Saudi Arabia. Arab J Geosci 4:825-835

Al-Laboun AA (1993) Lexicon of the Palaeozoic and Lower Mesozoic of Saudi Arabia, Part 1, lithostratigraphic units, nomenclature review. Al-Hudhud Publishers, Riyadh

Al-Laboun AA (2000) The Paleozoic geology of the Wajid area: a new approach. 4th Middle East Geosciences Conference, GEO 2000, Abstract. GeoArabia 5:26-27

Al-Laboun AA (2009) Tectonostratigraphy of the exposed Silurian deposits in Arabia. Arab J Geosci 2:119-131

Al-Laboun AA (2010) Paleozoic tectono-stratigraphic framework of the Arabian Peninsula. J King Saud Univ Sci 22:41-50

Al-Laboun AA (2011) Tectono-history of the Silurian Sharawra Formation in northwestern and central Arabia. Egypt J Pure Appl Sci 49:1-7

Al-Laboun AA (2013) Regional tectonic and megadepositional cycles of the Paleozoic of northwestern and central Saudi Arabia. Arab J Geosci 6:971-984

Al-Ramadan KA, Hussain M, Imam B, Saner S (2004) Lithologic characteristics of the Devonian Jauf sandstone at Ghawar Field, eastern Saudi Arabia. Mar Petrol Geol 21:12211234

Alsharhan AS (1994) Geology and hydrocarbon occurrences of the clastic PermoCarboniferous in the central and eastern Arabian Basin. Geol Mijnbouw 73a:63-73

Alsharhan AS, Nairn AEM (1997) Sedimentary basins and petroleum geology of the Middle East. Elsevier, Amsterdam 
Armstrong-Altrin JS (2015) Evaluation of two multidimensional discrimination diagrams from beach and deep-sea sediments from the Gulf of Mexico and their application to Precambrian clastic sedimentary rocks. Int Geol Rev 57:1446-1461

Armstrong-Altrin JS, Verma SP (2005) Critical evaluation of six tectonic setting discrimination diagrams using geochemical data of Neogene sediments from known tectonic settings. Sediment Geol 177:155-129

Avigad D, Sandler A, Kolodner K, Stern RJ, McWilliams M, Miller N, Beyth M (2005) Massproduction of Cambro-Ordovician quartz-rich sandstone as a consequence of chemical weathering of Pan-African terranes: environmental implications. Earth Planet Sci Lett 240:818-826

Babalola LO (1999) Depositional environments and provenance of the Wajid Sandstone, Abha-Khamis Mushayt area, Southwestern Saudi Arabia. MSc Thesis, King Fahd University of Petroleum and Minerals, Dhahran, Saudi Arabia

Babalola LO, Hussain M, Hariri MM (2003) Origin of iron-rich beds in the basal Wajid Sandstone, Abha-Khamis Mushayt area, southwest Saudi Arabia. Arab J Sci Eng 28(1A):3-24

Bahlburg H, Dobrzinski N (2011) A review of the chemical index of alteration (CIA) and its application to the study of Neoproterozoic glacial deposits and climate transitions. Geol Soc London Mem 36: 81-92

Bassis A, Hinderer M, Meinhold G (2016) New insights into the provenance of Saudi Arabian Palaeozoic sandstones from heavy mineral analysis and single-grain geochemistry. Sediment Geol 333:100-114

Bauluz B, Mayayo MJ, Fernandez-Nieto C, Lopez JMG (2000) Geochemistry of Precambrian and Paleozoic siliciclastic rocks from the Iberian Range (NE Spain): implications for sourcearea weathering, sorting, provenance, and tectonic setting. Chem Geol 168:135-150

Bhatia MR (1983) Plate tectonics and geochemical composition of sandstones. J Geol 91:611-627

Bhatia MR, Crook KAW (1986) Trace element characteristics of graywackes and tectonic setting discrimination of sedimentary basins. Contrib Mineral Petr 92:181-193

Bishop RS (1995) Maturation history of the lower Palaeozoic of the eastern Arabian Platform. In: Al-Husseini MI (ed) Middle East petroleum geosciences, GEO'94 1:180-189

Bracciali L, Marroni M, Pandolfi L, Rocchi S (2007) Geochemistry and petrography of western Tethys Cretaceous sedimentary covers (Corsica and northern Apennines): from source areas to configuration of margins. In: Arribas J, Critelli S, Johnsson MJ (eds), Sedimentary provenance and petrogenesis: perspectives from petrography and geochemistry, vol. 420, Geol Soc Am Spec Pap, pp 73-93

Breuer P, Miller MA, Leszczyński S, Steemans P (2015) Climate-controlled palynofacies and miospore stratigraphy of the Jauf Formation, Lower Devonian, northern Saudi Arabia. Rev Palaeobot Palynol 212:187-213 
BRGM (1985) Water, agriculture and soil studies of Saq and overlying aquifers. Unpublished report, Ministry of Agriculture and Water, Water Resources Development Department, Kingdom of Saudi Arabia

Cardenas AA, Girty GH, Hanson AD, Lahren MM, Knaack C, Johnson D (1996) Assessing differences in composition between low metamorphic grade mudstones and high-grade schists using logratio techniques. J Geol 104:279-293

Chandler FW(1988) Quartz arenites: review and interpretation. Sediment Geol 58:105-126

Cingolani CA, Manassero M, Abre P (2003) Composition, provenance, and tectonic setting of Ordovician siliciclastic rocks in the San Rafael block: southern extension of the Precordillera crustal fragment, Argentina. J S Am Earth Sci 16:91-106

Clayton G, Owens B, Al-Hajri S, Filatoff J (2000) Latest Devonian and Early Carboniferous miospore assemblages from Saudi Arabia. In: Al-Hajri S, Owens B (eds) Stratigraphic palynology of the Palaeozoic of Saudi Arabia. GeoArabia Special Publication 1, Gulf PetroLink, Bahrain, pp 146-153

Cullers RL, Podkovyrov VN (2002) The source and origin of terrigenous sedimentary rocks in the Mesoproterozoic Ui group, southeastern Russia. Precambrian Res 117:157-183

Das BK, Al-Mikhlafi AS, Kaur P (2006) Geochemistry of Mansar Lake sediments, Jammu, India: implication for source-area weathering, provenance, and tectonic setting. J Asian Earth Sci 26:649-668

Dickinson WR, Suczek CA (1979) Plate tectonics and sandstone composition. AAPG Bull 63:2164-2182

Dickinson WR, Beard LS, Brackenbridge GR, Erjavec JL, Ferguson RC, Inman KF, Knepp RA, Lindberg FA, Ryberg PT (1983) Provenance of North American Phanerozoic sandstones in relation to tectonic setting. Geol Soc Am Bull 94:222-235

Duzgoren-Aydin NS, Aydin A, Malpas J (2002) Re-assessment of chemical weathering indices: case study on pyroclastic rocks of Hong Kong. Eng Geol 63:99-119

Edgell HS (1997) Aquifers of Saudi Arabia and their geological framework. Arab J Sci Eng 22(1C):3-31

Etemad-Saeed N, Hosseini-Barzi M, Armstrong-Altrin JS (2011) Petrography and geochemistry of clastic sedimentary rocks as evidences for provenance of the Lower Cambrian Lalun Formation, Posht-e-badam block, central Iran. J Afr Earth Sci 61:142-159

Evans DS, Lathon RB, Senalp M, Connally TC (1991) Stratigraphy of the Wajid Sandstone of southwestern Saudi Arabia. proceedings of the 7th Society of Petroleum Engineers Middle East Oil Show, Bahrain, 16-19th November, 1991. SPE Paper 21449:947-960

Fedo CM, Nesbitt HW, Young GM (1995) Unraveling the effects of potassium metasomatism in sedimentary rocks and paleosols, with implications for paleoweathering conditions and provenance. Geology 23:921-924 
Ghienne JF (2003) Late Ordovician sedimentary environments, glacial cycles, and postglacial transgression in the Taoudeni Basin, West Africa. Palaeogeogr Palaeoclimatol Palaeoecol 189:117-145

Ghienne JF, Deynoux M (1998) Large-scale channel-fill structures in Late Ordovician glacial deposits in Mauritania, western Sahara. Sediment Geol 119:141-159

Ghienne JF, Deynoux M, Manatschal G, Rubino JL (2003) Palaeovalleys and fault-controlled depocentres in the Late Ordovician glacial record of the Murzuq Basin (central Libya). Compt Rendus Geosci 335:1091-1100

GTZ/DCo (2009) Detailed water resources studies of Wajid and overlying aquifers, volume 10. Drilling Investigations. Unpublished report, Ministry of Water and Electricity, Riyadh

Hammer $\varnothing$, Harper DAT, Ryan PD (2001) PAST: paleontological statistics software package for education and data analysis. Palaeontol Electron 4:1-9

Hinderer M, Keller M, Al-Ajmi H, Rausch R (2009) Tales of two glaciations in the Paleozoic of SW Saudi Arabia: implications for ice shield dynamics and paleogeography of the SW Arabian Platform and adjacent areas. ILP Task Force on Sedimentary Basins, 2009 International Workshop, Abu Dhabi

Hints O, Paris F, Al-Hajri S (2015) Late Ordovician scolecodonts from the Qusaiba-1 core hole, central Saudi Arabia, and their paleogeographical affinities. Rev Palaeobot Palynol 212:85-96

Huntsman-Mapila P, Tiercelin J-J, Benoit M, Ringrose S, Diskin S, Cotton J, Hémond C (2009) Sediment geochemistry and tectonic setting: application of discrimination diagrams to early stages of intracontinental rift evolution, with examples from the Okavango and Southern Tanganyika rift basins. J Afr Earth Sci 53:33-44

Hussain M (2001) Framework mineralogy, diagenesis and provenance of the Wajid Sandstone in Asir region, southwestern Saudi Arabia. Report, KACST Project no. LPG 283

Hussain M (2007) Elemental chemistry as a tool of stratigraphic correlation: a case study involving lower Paleozoic Wajid, Saq, and Qasim Formations in Saudi Arabia. Mar Petrol Geol 24:91-108

Hussain M, Abdullatif OM (2004) Trace element geochemistry and heavy mineral assemblage of the Cambro-Ordovician Saq Sandstone of the Tabuk Basin and its possible correlation with the Wajid Sandstone of the Wajid Basin, southwest Saudi Arabia. Report, KACST Project LGP 6-54

Hussain M, Babalola LO, Hariri M (2000) Provenance of the Wajid Sandstone, southeastern margin of the Arabian shield: geochemical and petrographic approach. American Association of Petroleum Geologists National Conference, New Orleans, USA, April 16, 1999, Extended Abstracts with Programs: 7 
Hussain M, Babalola LO, Hariri MM (2004) Heavy minerals in the Wajid Sandstone from Abha-Khamis Mushayt area, southwestern Saudi Arabia: implications on provenance and regional tectonic setting. GeoArabia 9:77-102

Jackson NJ, Douch CJ (1986) Jabal Hamra REE-mineralized silexite, Hijaz region, Kingdom of Saudi Arabia. J Afr Earth Sci 4:269-274

Jackson NJ, Walsh JN, Pegram E (1984) Geology, geochemistry and petrogenesis of late Precambrian granitoids in the Central Hijaz Region of the Arabian Shield. Contrib Mineral Petrol 87:205-219

Janoušek V, Farrow CM, Erban V (2006) Interpretation of whole-rock geochemical data in igneous geochemistry: introducing Geochemical Data Toolkit (GCDkit). J Petrol 47:12551259

Johnson PR, Andresen A, Collins AS, Fowler AR, Fritz H, Ghebreab W, Kusky T, Stern RJ (2011) Late Cryogenian-Ediacaran history of the Arabian-Nubian Shield: A review of depositional, plutonic, structural, and tectonic events in the closing stages of the northern East African Orogen. J Afr Earth Sci 61:167-232

Johnsson MJ (1993) The system controlling the composition of clastic sediments. In: Johnsson MJ, Basu A (eds) Processes controlling the composition of clastic sediments, vol. 284, Geol Soc Am Spec Pap, pp 1-20

Keller M, Hinderer M, Al-Ajmi HF, Rausch R (2011) Palaeozoic glacial depositional environments of SW Saudi Arabia: process and product. In: Martini IP, French HM, Pérez Alberti A (eds) Icemarginal and periglacial processes and sediments, vol 354, Geol Soc London Spec Publ, pp 129-152

Kellogg KS, Janjou D, Minoux L, Fourniguet J (1986) Explanatory notes to the geologic map of the Wadi Tathlith Quadrangle, Kingdom of Saudi Arabia. Geoscience Map GM-103C, scale 1:250,000, sheet 20G. Deputy Ministry for Mineral Resources, Ministry of Petroleum and Mineral Resources, Kingdom of Saudi Arabia

Khalifa MA (2015) Glacial and post-glacial deposits of the Unayzah Formation (Carboniferous-Permian), Saudi Arabia: facies analysis and sequence stratigraphy. Carbonate Evaporite 30:207-227

Knox RWO'B, Franks SG, Cocker JD (2007) Stratigraphic evolution of heavy-mineral provenance signatures in the sandstones of the Wajid Group (Cambrian to Permian), Saudi Arabia. GeoArabia 12:65-96

Knox RWO'B, Cocker JD, Filatoff J (2010) Heavy mineral stratigraphy of the Unayzah Formation and Basal Khuff Clastics (Carboniferous to Permian) of central Saudi Arabia. GeoArabia 15:17-80

Kolodner K, Avigad D, McWilliams M, Wooden JL, Weissbrod T, Feinstein S (2006) Provenance of north Gondwana Cambrian-Ordovician sandstone: U-Pb SHRIMP dating of detrital zircons from Israel and Jordan. Geol Mag 143:367-391 
Konert G, Al-Afifi AM, Al-Hajri SA, Droste HJ (2001) Paleozoic stratigraphy and hydrocarbon habitat of the Arabian Plate. GeoArabia 6:407-442

Le Hérissé A, Molyneux SG, MillerMA (2015) Late Ordovician to early Silurian acritarchs from the Qusaiba-1 shallow core hole, central Saudi Arabia. Rev Palaeobot Palynol 212:22-59

Le Heron D, Sutcliffe O, Bourgig K, Craig J, Visentin C, Whittington R (2004) Sedimentary architecture of Upper Ordovician tunnel valleys, Gargaf Arch, Libya: implications for the genesis of a hydrocarbon reservoir. GeoArabia 9:137-160

Le Heron DP, Sutcliffe OE, Whittington RJ, Craig J (2005) The origins of glacially related softsediment deformation structures in Upper Ordovician glaciogenic rocks: implication for ice sheet dynamics. Palaeogeogr Palaeoclimatol Palaeoecol 218:75-103

Le Heron DP, Craig J, Etienne JP (2009) Ancient glaciations and hydrocarbon accumulations in North Africa and the Middle East. Earth-Sci Rev 93:47-76

Le Heron DP, Armstrong HA, Wilson C, Howard JP, Gindre L (2010) Glaciation and deglaciation of the Libyan Desert: the Late Ordovician record. Sediment Geol 223:100-125

Le Heron DP, Meinhold G, Bergig K (2013) Neoproterozoic-Devonian stratigraphic evolution of the eastern Murzuq Basin, Libya: a tale of tilting in the central Sahara. Basin Res 25:5273

Le Heron DP, Meinhold G, Elgadry M, Abutarruma Y, Boote D (2015) Early Palaeozoic evolution of Libya: perspectives from Jabal Eghei with implications for hydrocarbon exploration in Al Kufrah Basin. Basin Res 27:60-83

Leo GW (1986) Geochemical reconnaissance of late Proterozoic volcanic and mafic plutonic rocks of the Al 'Awshaziyah Quadrangle and related rocks in the Qufar Quadrangle, northern Arabian Shield. U S Geol Surv Bull 1680:16

Lüning S, Craig J, Loydell DK, Štorch P, Fitches B (2000) Lower Silurian 'hot shales' in North Africa and Arabia: regional distribution and depositional model. Earth-Sci Rev 49:121-200

McBride EF (1963) A classification of common sandstones. J Sediment Petrol 33:664-669

McClure HA (1978) Early Paleozoic glaciation in Arabia. Palaeogeogr Palaeoclimatol Palaeoecol 25:315-326

McDonough WF, Sun SS (1995) The composition of the Earth. Chem Geol 120:223-253

McGillivray JG, Husseini MI (1992) The Palaeozoic petroleum geology of central Arabia. AAPG Bull 76:1473-1490

McLennan SM (1989) Rare earth elements in sedimentary rocks: influence of provenance and sedimentary processes. In: Lipin BR, McKay GA (eds) Geochemistry and mineralogy of rare earth elements, vol 21, Rev Mineral, pp 169-200 
McLennan SM (2001) Relationships between the trace element composition of sedimentary rocks and upper continental crust. Geochem Geophys Geosyst 2(4). doi:10.1029/2000GC000109

McLennan SM, Hemming S, McDaniel DK, Hanson GN (1993) Geochemical approaches to sedimentation, provenance and tectonics. In: Johnsson MJ, Basu A (eds) Processes controlling the composition of clastic sediments. Geol Soc Am, Boulder, pp. 21-40

Meinhold G, Kostopoulos D, Reischmann T (2007) Geochemical constraints on the provenance and depositional setting of sedimentary rocks from the islands of Chios, Inousses and Psara, Aegean Sea, Greece: implications for the evolution of Palaeotethys. J Geol Soc Lond 164:1145-1163

Meinhold G, Morton AC, Avigad D (2013a) New insights into peri-Gondwana paleogeography and the Gondwana super-fan system from detrital zircon $\mathrm{U}-\mathrm{Pb}$ ages. Gondwana Res 23:661-665

Meinhold G, Howard JP, Strogen D, Kaye MD, Abutarruma Y, Elgadry M, Thusu B, Whitham AG (2013b) Hydrocarbon source rock potential and elemental composition of lower Silurian subsurface shales of the eastern Murzuq Basin, southern Libya. Mar Petrol Geol 48:224-246

Meissner CR Jr, Mytton JW, Riddler GP, van Eck M, Aspinall NC, Farasini AM, Dini SM (1989) Preliminary geological map of the

Al Jawf Quadrangle, sheet 39D, Kingdom of Saudi Arabia. U S Geol Surv, Open-File Report 89-342

Melvin J, Norton AK (2013) Advances in Arabian stratigraphy: comparative studies of glaciogenic Juwayl and lower Unayzah strata (Carboniferous-Permian) of Saudi Arabia. GeoArabia 18:97-134

Melvin J, Sprague RA, Heine CJ (2010) From bergs to ergs: The late Paleozoic Gondwanan glaciation and its aftermath in Saudi Arabia. In: Lopez-Gamundi OR, Buatois LA (eds) Late Paleozoic glacial events and postglacial transgressions in Gondwana, vol 468, Geol Soc Am Spec Pap, pp 37-80

Melvin J (2015) Lithostratigraphy and depositional history of Upper Ordovician and lowermost Silurian sediments recovered from the Qusaiba-1 shallow core hole, Qasim region, central Saudi Arabia. Rev Palaeobot Palynol 212:3-21

Mongelli G, Critelli S, Perri F, Sonnino M, Perrone V (2006) Sedimentary recycling, provenance and paleoweathering from chemistry and mineralogy of Mesozoic continental redbed mudrocks, Peloritani mountains, southern Italy. Geochem J 40:197-209

Murali AV, Parthasarathy R, Mahadevan TM, Das MS (1983) Trace element characteristics, REE patterns and partition coefficients of zircons from different geological environmentsa case study on Indian zircons. Geochim Cosmochim Acta 47:2047-2052

Nesbitt HW, Young GM (1982) Early Proterozoic climates and plate motions inferred from major element chemistry of lutites. Nature 299:715-717 
Nesbitt HW, Young GM (1984) Prediction of some weathering trends of plutonic and volcanic rocks based on thermodynamic and kinetic considerations. Geochim Cosmochim Acta 48:1523-1534

Nesbitt HW, Young GM, McLennan SM, Keays RR (1996) Effects of chemical weathering and sorting on the petrogenesis of siliciclastic sediments, with implications for provenance studies. J Geol 104:525-542

Paris F, Miller AM, Al-Hajri S, Zalasiewicz J (2015a) Early Silurian chitinozoans from the Qusaiba type area, north Central Saudi Arabia. Rev Palaeobot Palynol 212:127-186

Paris F, Verniers J, Miller AM, Al-Hajri S, Melvin J, Wellman CH (2015b) Late Ordovicianearliest Silurian chitinozoans from the Qusaiba-1 core hole (north Central Saudi Arabia) and their relations to the Hirnantian glaciation. Rev Palaeobot Palynol 212:60-84

Pettijohn FJ (1954) Classification of sandstones. J Geol 62:360-365

Powers RW, Ramirez LF, Redmond CD, Elberg EL Jr (1966) Geology of the Arabian Peninsula: sedimentary geology of Saudi Arabia. U S Geol Surv Prof Pap 560-D

Ramsay CR, Drysdall AR, Clark MD (1986) Felsic plutonic rocks of the Midyan Region, Kingdom of Saudi Arabia - I. Distribution, classification and resource potential. J Afr Earth Sci 4:63-77

Roser BP, Korsch RJ (1986) Determination of tectonic setting of sandstone-mudstone suites using $\mathrm{SiO}_{2}$ content and $\mathrm{K}_{2} \mathrm{O} / \mathrm{Na}_{2} \mathrm{O}$ ratio. J Geol 94:635-650

Roser BP, Korsch RJ (1988) Provenance signatures of sandstone-mudstone suites determined using discriminant function analysis of major-element data. Chem Geol 67:119139

Rudnick RL, Gao S (2003) Composition of the continental crust. In: Rudnick R, Holland HD, Turekian KK (eds) Treatise on Geochemistry, vol 3, pp 1-64

Salman AS, Zaidi FK, Hussein MT (2014) Evaluation of groundwater quality in northern Saudi Arabia using multivariate analysis and stochastic statistics. Environ Earth Sci 74:7769-7782

Schubert M, Schüth C, Michelsen N, Rausch R, Al-Saud M (2011) Investigation and treatment of natural radioactivity in large-scale sandstone aquifer systems. Int J Water Resour Arid Environ 1:25-32

Schwab FL (1978) Modern and ancient sedimentary Utah. Sedimentology 25:97-109

Senalp M, Al-Duaiji A (1995) Stratigraphy and sedimentation of the Unayzah reservoir, central Saudi Arabia. In: Al-Husseini MI (ed) Middle East petroleum geosciences conference, GEO'94. Gulf PetroLink, Bahrain, pp. 837-847

Senalp M, Al-Laboun AA (2000) New evidence on the Late Ordovician glaciation in central Saudi Arabia. Saudi Aramco Journal of Technology, Spring 2000:11-40 
SGS (2013) Phanerozoic Stratigraphy of Saudi Arabia Part 1 - Paleozoic Successions of the Arabian Shelf (cover rocks). Saudi Strat Comm Spec Publ 1:1-69

Sharland PR, Archer R, Casey DM, Davies RB, Hall SH, Heward AP, Horbury AD, Simmons MD (2001) Arabian Plate sequence stratigraphy. GeoArabia Special Publication 2, Gulf PetroLink, Bahrain

Sharland PR, Casey DM, Davies RB, SimmonsMD, Sutcliffe OE (2004) Arabian Plate sequence stratigraphy. GeoArabia 9:199-214

Squire RJ, Campbell IH, Allen CM, Wilson JL (2006) Did the Transgondwanan supermountain trigger the explosive radiation of animals on Earth? Earth Planet Sci Lett 250:116-133

Steineke MRA, Bramkamp RA, Sander NJ (1958) Stratigraphic relations of Arabian Jurassic oil. In: Weeks LG (ed) Habitat of oil. American Association of Petroleum Geologists Symposium, Tulsa, OK, pp. 1294-1329

Stephenson MH (2004) Early Permian spores from Oman and Saudi Arabia. GeoArabia Spec Publ 3:185-215

Stuckless JS, Van Trump G Jr, Moore WJ, Bartel AJ, Vaughn RB, Bush CA (1985) Geochemistry and preliminary assessment of resource potential for postorogenic granites of the eastcentral Arabian Shield, Kingdom of Saudi Arabia. U S Geol Surv, Open-File Report USGS-OF05-26

Stuckless JS, Vaughn RB, Van Trump G Jr (1986) Trace-element contents of postorogenic granites of the eastern Arabian Shield, Kingdom of Saudi Arabia. U S Geol Surv, Open-File Report USGS-OF-06-2

Stump TE, Al-Hajri S, van der Eem JG (1995) Geology and biostratigraphy of the Late Precambrian through Paleozoic sediments of Saudi Arabia. Rev Palaeobot Palynol 89:5-17

Stump TE, van der Eem JG (1995) The stratigraphy, depositional environments and periods of deformation of the Wajid outcrop belt, southwestern Saudi Arabia. J Afr Earth Sci 21:421441

Taylor SR, McLennan SM (1985) The continental crust: its composition and evolution. Blackwell, Oxford

Taylor SR, McLennan SM (2009) Planetary crusts: their composition, origin and evolution. Cambridge University Press, Cambridge

Thralls HW, Hasson RC (1956) Geology and oil resources of eastern Saudi Arabia. 20th international geology Congress. Mexico and Symposium Sobre Yacimentos de Petroleum and Gas 2:9-32

Vaslet D (1990) Upper Ordovician glacial deposits in Saudi Arabia. Episodes 13:147-161

Verma SP, Armstrong-Altrin JS (2013) New multi-dimensional diagrams for tectonic discrimination of siliciclastic sediments and their application to Precambrian basins. Chem Geol 355:117-133 
von Eynatten H, Dunkl I (2012) Assessing the sediment factory: the role of single grain analysis. Earth-Sci Rev 115:97-120

von Eynatten H, Tolosana-Delgado R, Karius V (2012) Sediment generation in modern glacial settings: grain-size and source-rock control on sediment composition. Sediment Geol 280:80-92

Wanas HA, Abdel-Maguid NM (2006) Petrography and geochemistry of the CambroOrdovician Wajid Sandstone, southwest Saudi Arabia: implications for provenance and tectonic setting. J Asian Earth Sci 27:416-429

Wedepohl KH (1978) Handbook of geochemistry, volume II, part 2. Springer, Berlin, Heidelberg, New York

Weibel R, Johannessen PN, Dybkjær K, Rosenberg P, Knudsen C (2010) Chemostratigraphy of upper Jurassic reservoir sandstones, Danish Central Graben, North Sea. Mar Petrol Geol 27:1572-1594

Wellman CH, Steemans P, Miller MA (2015) Spore assemblages from Upper Ordovician and lowermost Silurian sediments recovered from the Qusaiba-1 shallow core hole, Qasim region, central Saudi Arabia. Rev Palaeobot Palynol 212:111-156

Weltje GJ (2002) Quantitative analysis of detrital modes: statistically rigorous confidence regions in ternary diagrams and their use in sedimentary petrology. Earth-Sci Rev 57:211253

Weltje GJ (2004) A quantitative approach to capturing the compositional variability of modern sands. Sediment Geol 171:59-77

Weltje GJ (2006) Ternary sandstone composition and provenance: an evaluation of the 'Dickinson model'. In: Buccianti A, Mateu-Figueras G, Pawlowsky-GlahnV (eds) Compositional data analysis: from theory to practice, vol 264, Geol Soc Spec Publ, pp 611627

Weltje GJ, von Eynatten H (2004) Quantitative provenance analysis of sediments: review and outlook. Sediment Geol 171:1-11

Weltje GJ, Meijer XD, de Boer PL (1998) Stratigraphic inversion of siliciclastic basin fills: a note on the distinction between supply signals resulting from tectonic and climatic forcing. Basin Res 10:129-153

Wender LE, Bryant JW, DickensMF, Neville AS, AI-Moqbel AM (1998) Paleozoic (pre-Khuff) hydrocarbon geology of the Ghawar area, eastern Saudi Arabia. GeoArabia 3:273-302

Wronkiewicz DJ, Condie KC (1987) Geochemistry of Archean shales from the Witwatersrand supergroup, South Africa: source-area weathering and provenance. Geochim Cosmochim Acta 51:2401-2416 
Young GM, Minter WEL, Theron JN (2004) Geochemistry and palaeogeography of upper Ordovician glaciogenic sedimentary rocks in the Table Mountain Group, South Africa. Palaeogeogr Palaeoclimatol Palaeoecol 214:323-345

\section{Figure captions}

Fig. 1. a Simplified geologic map of the Arabian Peninsula showing the study areas, b geologic map of the southern Saudi Arabian study area ('Wajid area') and c geologic map of the northern Saudi Arabian study area ('Tabuk area') (modified after Bassis et al. 2016)

Fig. 2. Simplified stratigraphic column of both study areas. Modified after (1) Al-Ajmi et al. (2015), (2) Al-Laboun (2010) and (3) Sharland et al. (2001)

Fig. 3. QFL diagrams for lithological classification (modified after McBride 1963): a Tabuk area and $\mathbf{b}$ Wajid area

Fig. 4. Thin section photographs of Palaeozoic sandstones: left-hand side regular view and right-hand side with crossed polarisers. a, b Highly mature and well sorted quartz arenite from the Dibsiyah Formation (AB-SA79), typical for most of the Palaeozoic succession. $\mathbf{c}, \mathbf{d}$ arkose from the Juwayl Formation (AB-SA98) with strong calcitic cementation; two generations of feldspar are visible, displaying highly different degrees of weathering. $\mathbf{e}, \mathbf{f}$ Poorly sorted subarkose from the Unayzah Formation (AB-SA120) with large grains of feldspar and $Q p$

Fig. 5. Th/Sc versus $\mathrm{Zr} / \mathrm{Sc}$ plot (modified after McLennan et al. 1993) showing zircon enrichment interpreted as sedimentary recycling; UCC (from McLennan 2001; Taylor and McLennan 2009) and an idealised compositional trend (from Mongelli et al. 2006) have been plotted for comparison: a data from Palaeozoic sediments, grey arearepresents literature data (from Hussain 2007) and b data from selected basement rocks of the Arabian Shield (from Jackson et al. 1984; Stuckless et al. 1985, 1986; Jackson and Douche 1986; Leo 1986; Ramsay et al. 1986; and own samples), grey area represents Palaeozoic sediments from Fig. $5 a$

Fig. 6. Tectonic discrimination diagrams after Roser and Korsch (1986) (a, b) and after Verma and Armstrong-Altrin (2013) (c, d) for the Tabuk (left side) and Wajid (right side) areas. PM passive margin, ACM active continental margin, ARC ocean island arc; grey arearepresents 
literature data (from Hussain 2001; Babalola et al. 2003; Al-Harbi and Khan 2005, 2008, 2011); grey symbols in (d) are Wajid samples from the 2009-2010 field campaign

Fig. 7. Provenance discrimination diagrams after Roser and Korsch (1988) (a, b) and ternary $\mathrm{Ni}-\mathrm{V}-\mathrm{Th} * 10$ diagrams for source rock discrimination (modified after Bracciali et al. (2007) (c, d) for the Tabuk (left side) and Wajid (right side) areas; light grey arearepresents literature data (from Hussain 2001; Al-Harbi and Khan 2011); dark grey areas represent idealised source rock end-members; PAAS (from Taylor and McLennan 1985; McLennan 2001) and UCC (from Rudnick and Gao 2003) have been added for comparison

Fig. 8. Scatter plot of the two most significant components of a principal component analysis (PCA); different symbols and colours represent samples from upper and lower successions from both study areas; the first two principal components accounted for $67.4 \%$ of the total variance of the dataset; $\mathbf{a}$ arrangement of samples and $\mathbf{b}$ biplot of variables; dotted area represents range of samples from Khusayyayn and Juwayl formations; dashed area represents range of samples from Dibsiyah and Sanamah formations, without outliers; c scree plot of principal components versus eigenvalues

Tables

Table 1. Palaeozoic sampling sites and outcrops with GPS coordinates

Table 2. Modal composition and framework mineralogy for Palaeozoic sandstones. The Qusaiba and Sharawra members of the Qalibah Formation are listed under 'Formation' for convenience. Because of the limited space in the table, the sample prefix 'AB-SA' has been omitted in the first column 


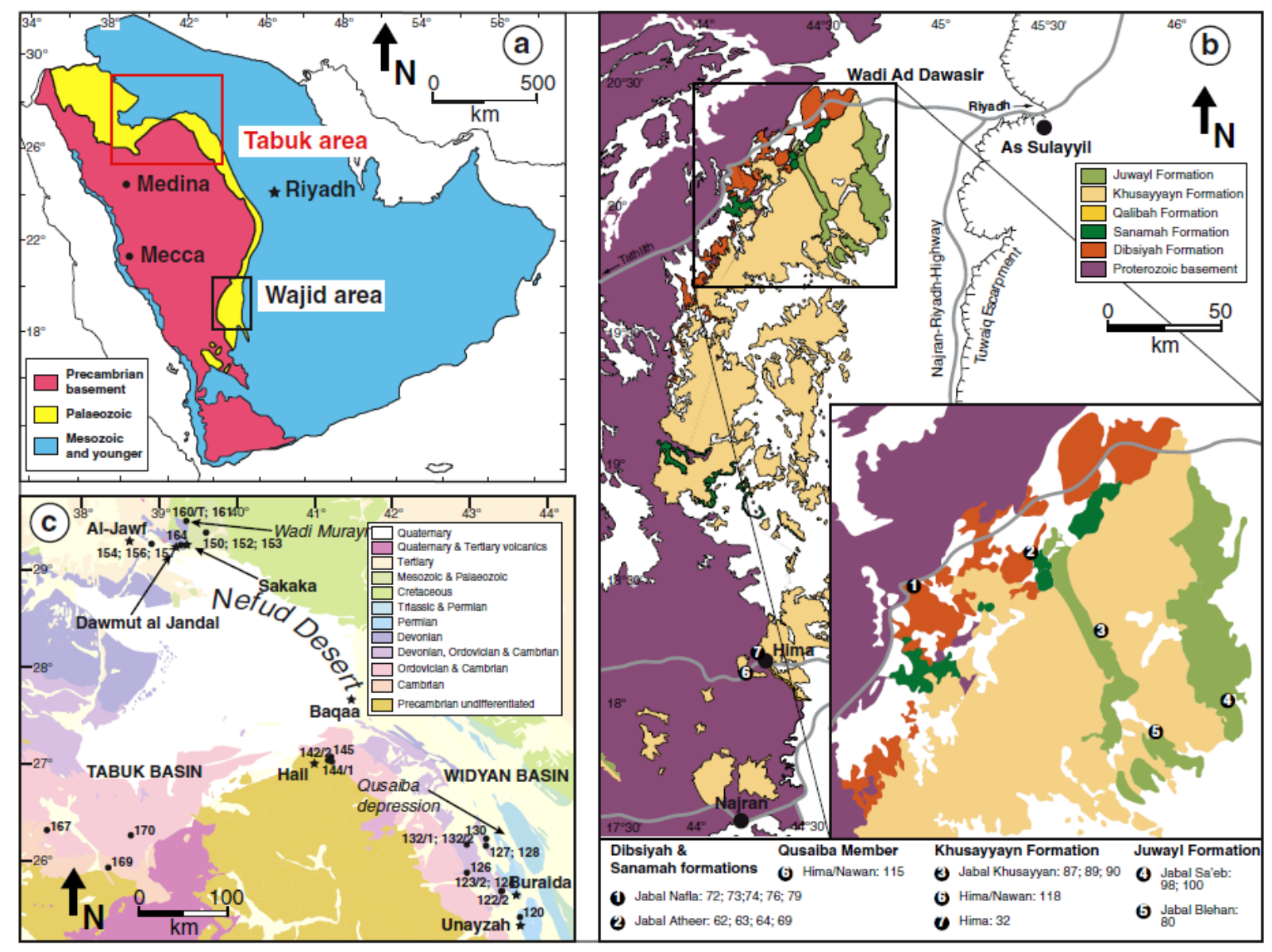

Fig. 1 


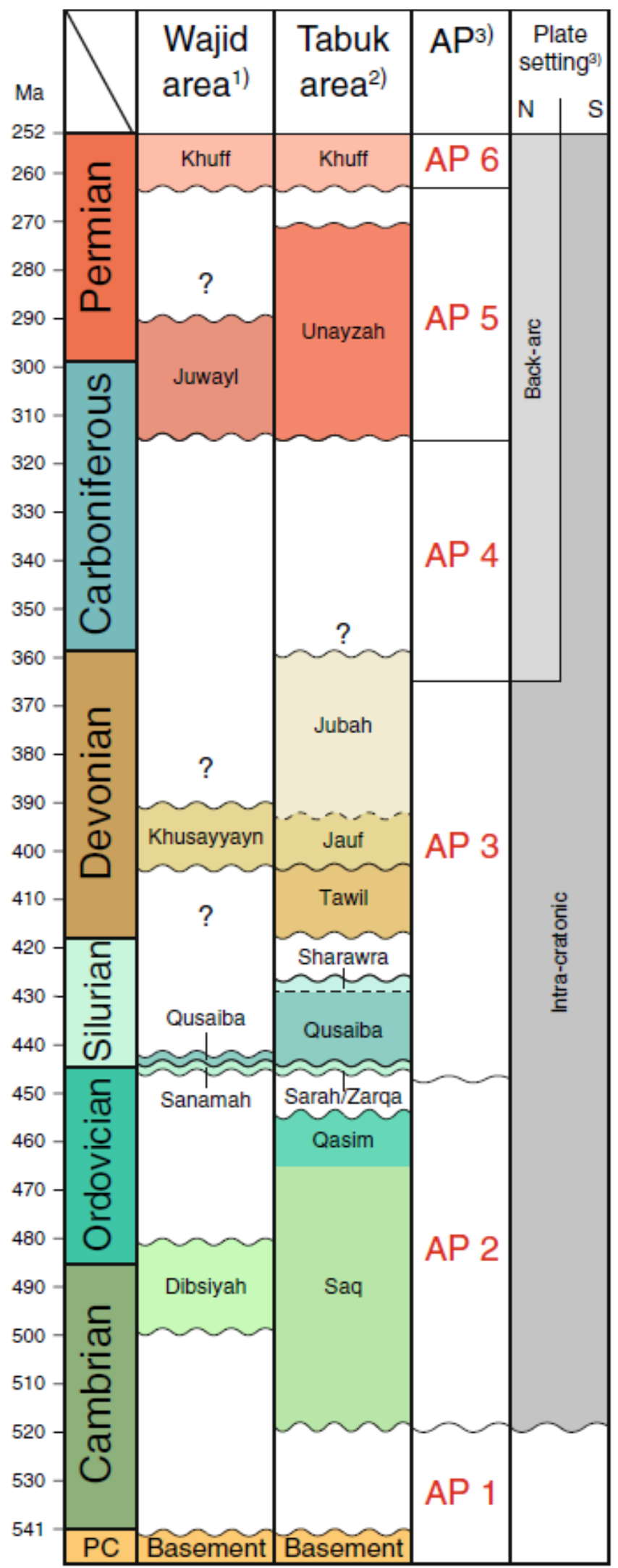

Fig. 2 


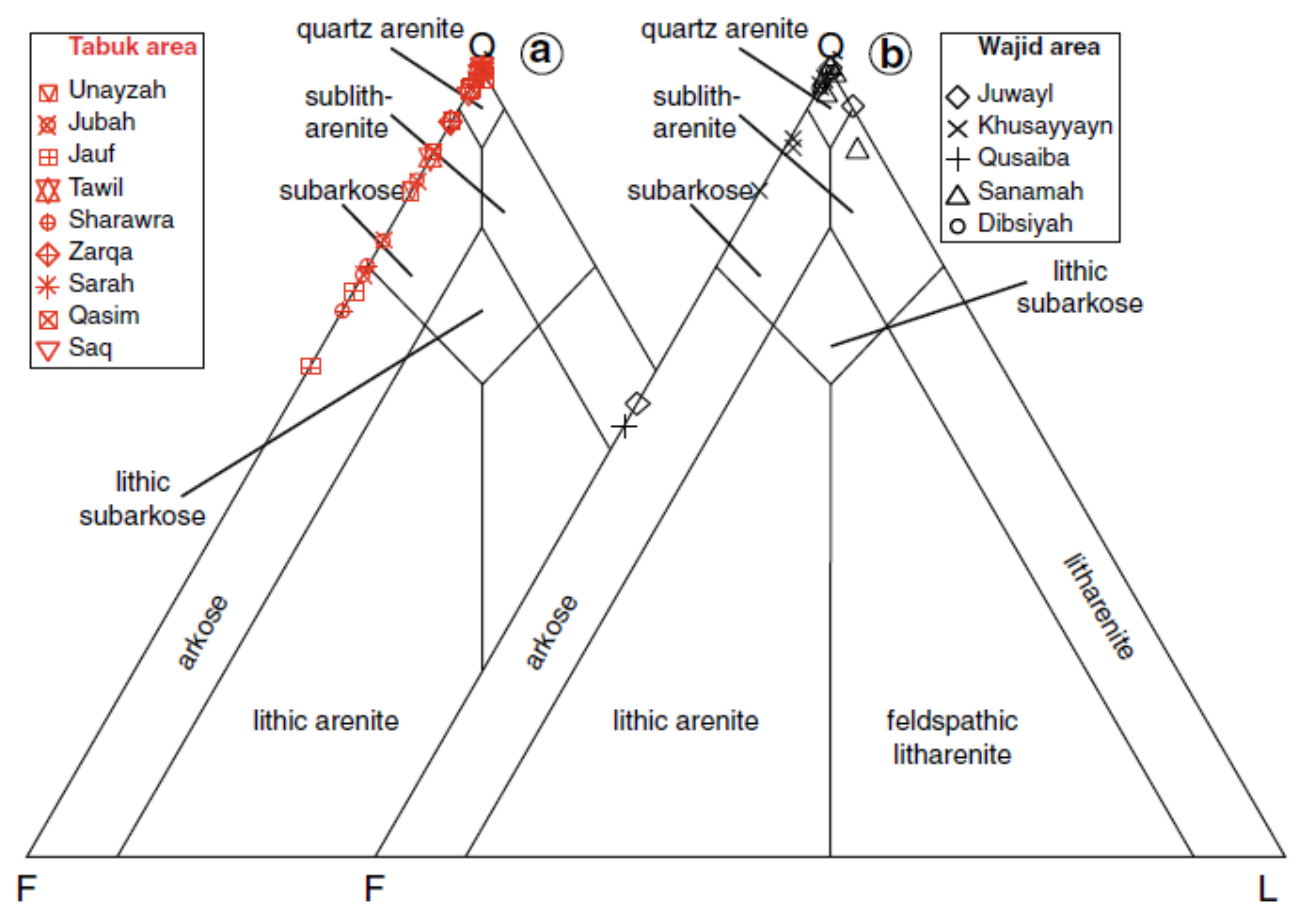

Fig. 3 

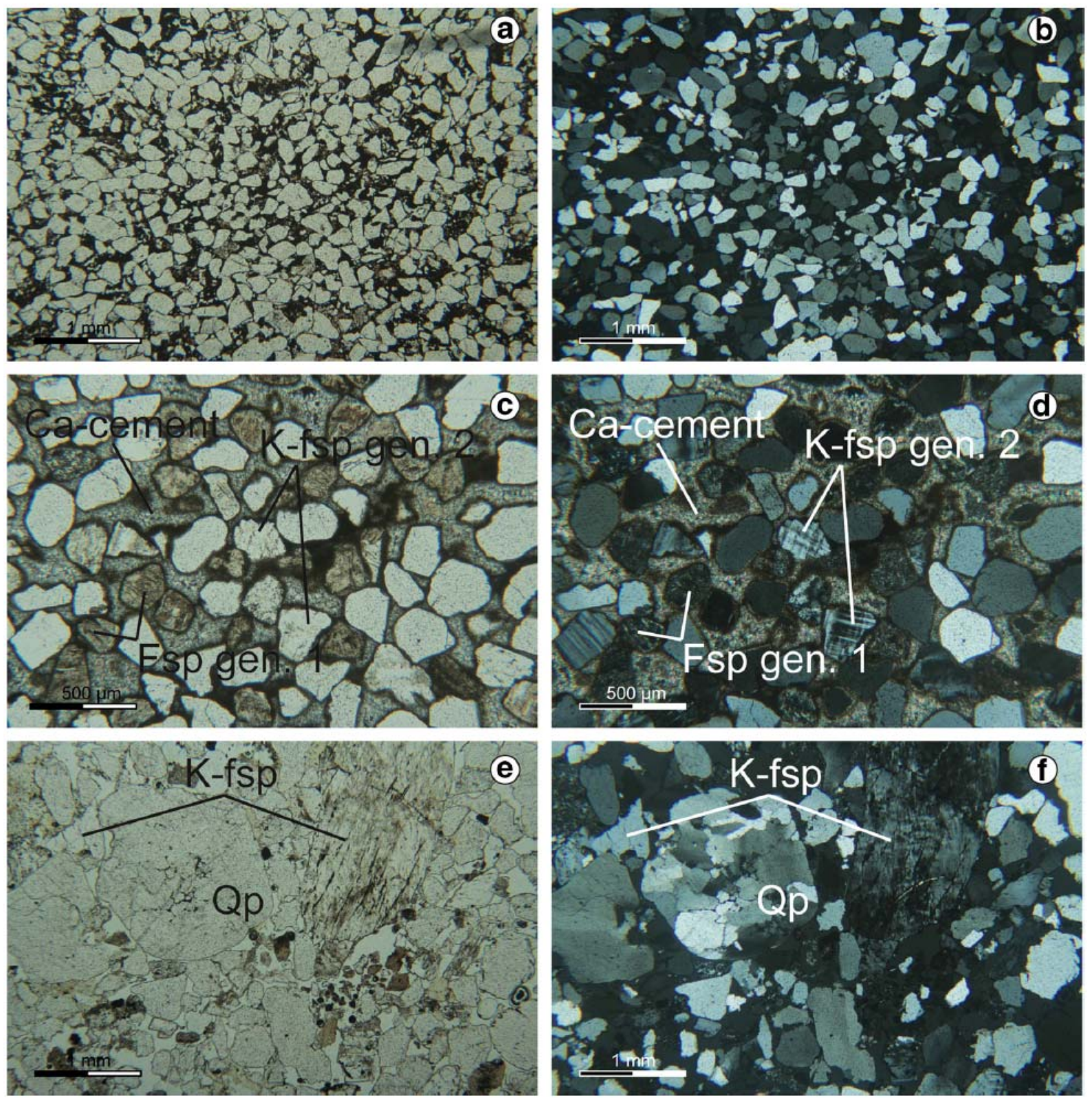

Fig. 4 

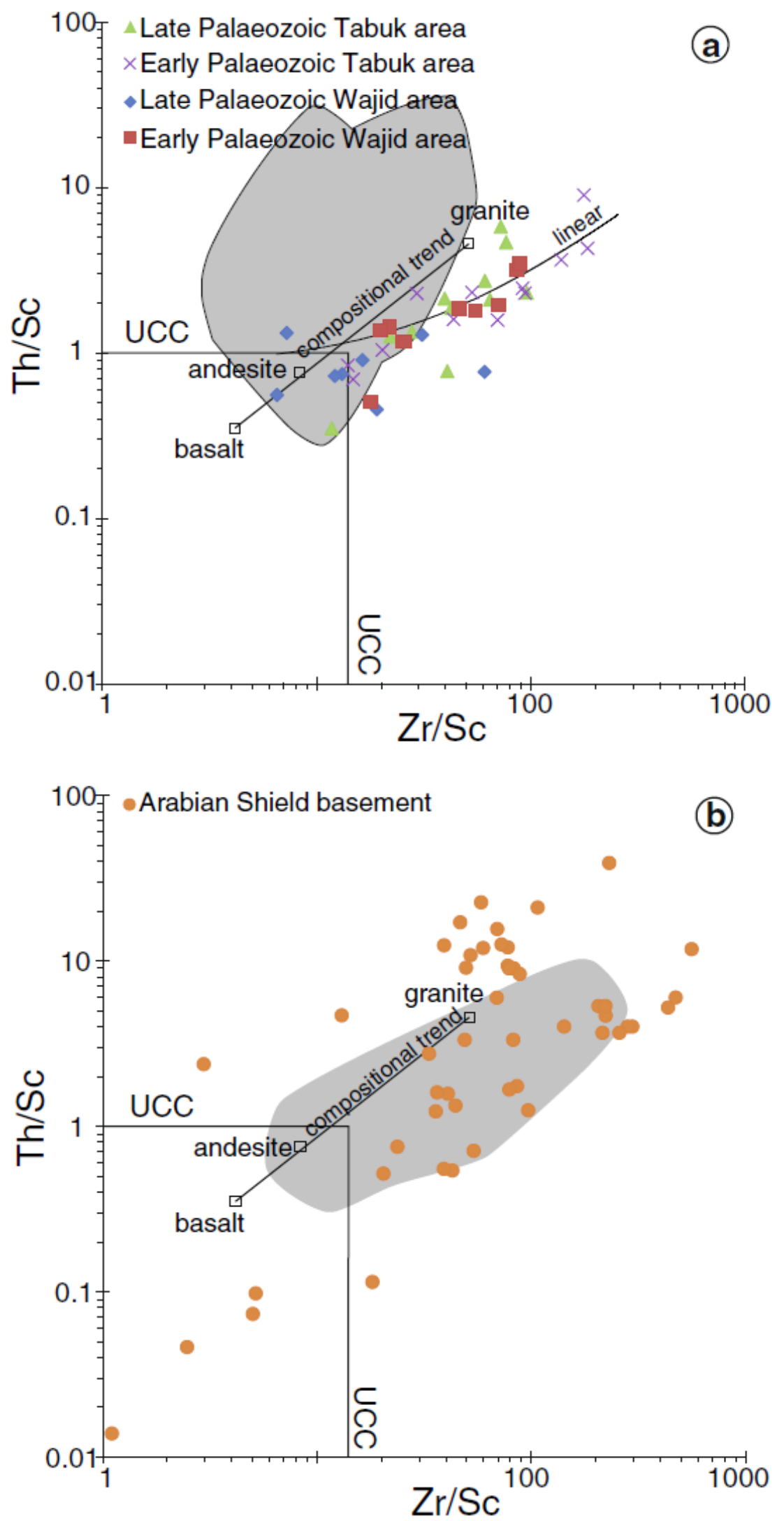

Fig. 5 

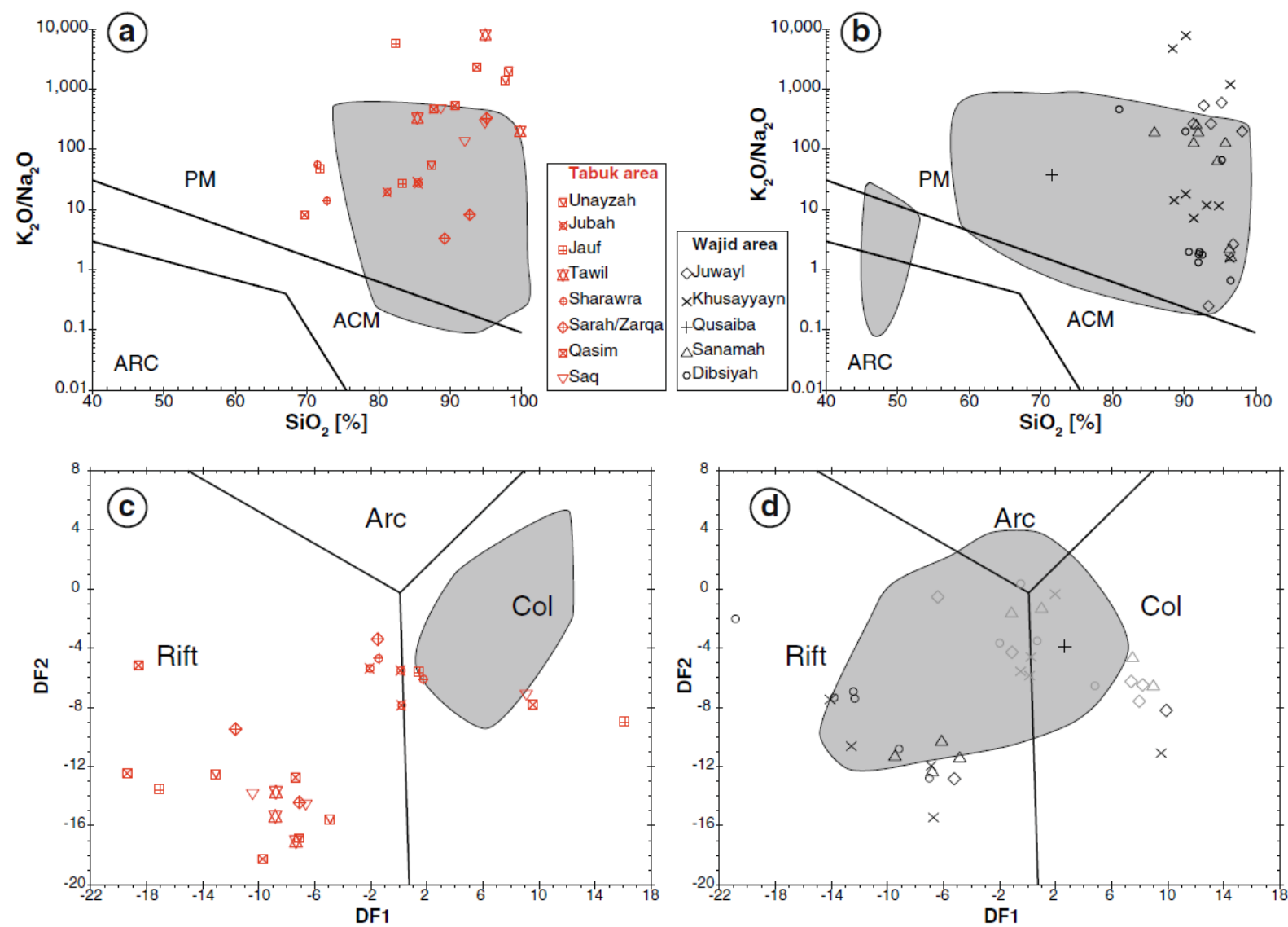

Fig. 6 

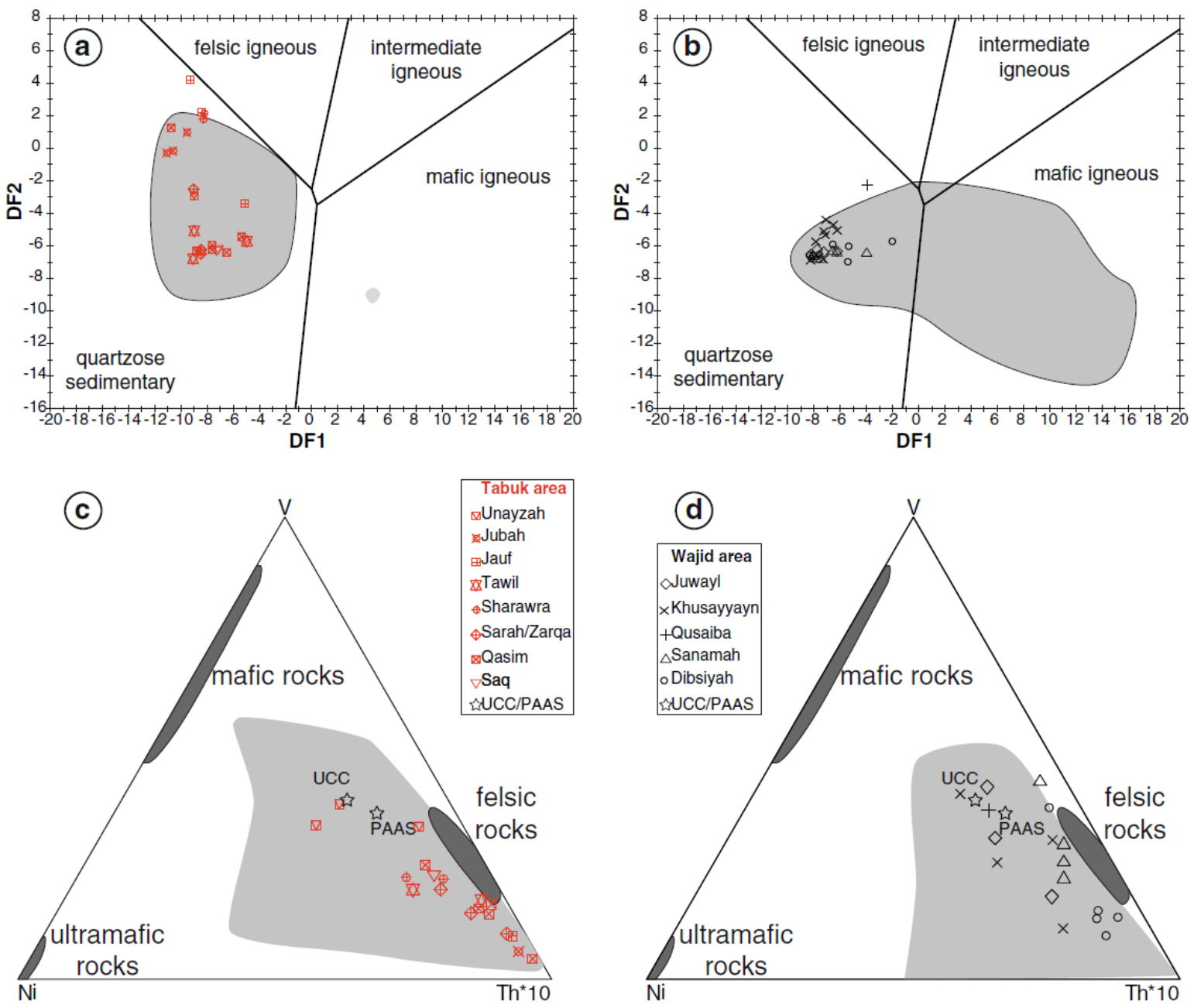

Fig. 7 


\section{(a)}
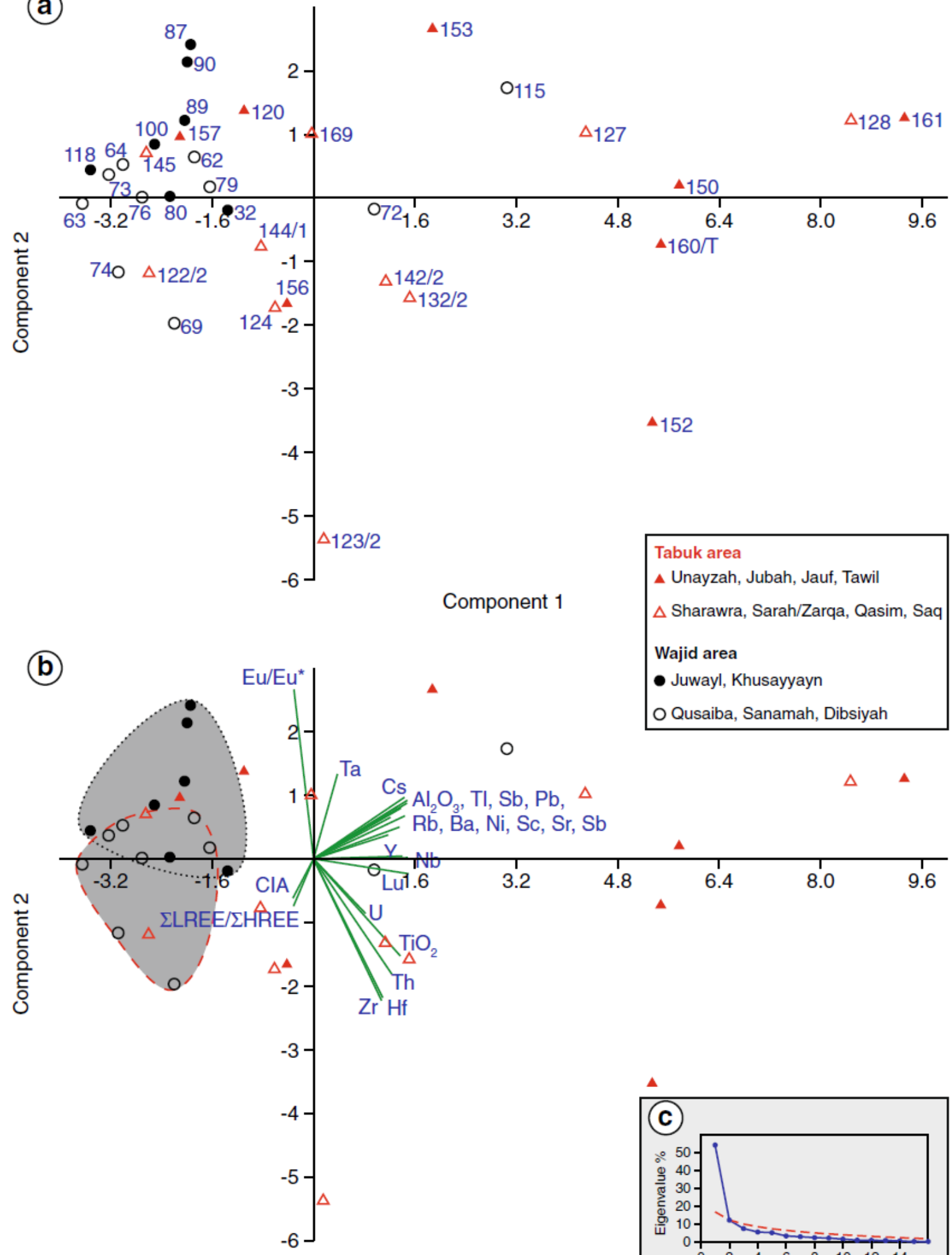

o

$\mathrm{Al}_{2} \mathrm{O}_{3}, \mathrm{TI}, \mathrm{Sb}, \mathrm{Pb}, \quad \Delta$

$\mathrm{Rb}, \mathrm{Ba}, \mathrm{Ni}, \mathrm{Sc}, \mathrm{Sr}, \mathrm{Sb}$

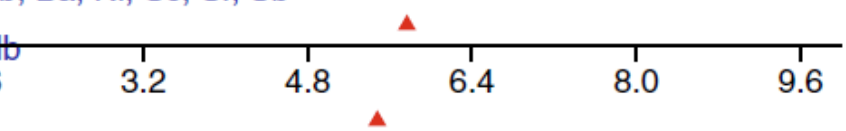

Component 1

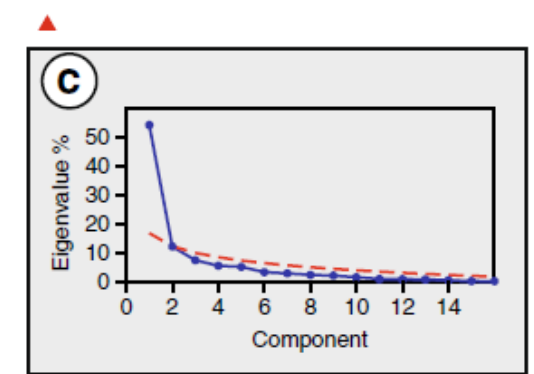

Fig. 8 
Table 1

\begin{tabular}{|c|c|c|c|c|c|}
\hline Sample no. & Age & Stratigraphy & Latitude & Longitude & Location \\
\hline \multicolumn{6}{|l|}{ Tabuk area } \\
\hline AB-SA120 & Carboniferous-Permian & Unayzah Fm. & $26^{\circ} 07^{\prime} 30.1^{\prime \prime}$ & $43^{\circ} 59^{\prime} 11.7^{\prime \prime}$ & Buraida-Unayzah road \\
\hline AB-SA129 & Carboniferous-Permian & Unayzah Fm. & $26^{\circ} 55^{\prime} 35.9^{\prime \prime}$ & $43^{\circ} 34^{\prime} 39.8^{\prime \prime}$ & E of Qusaiba depressic \\
\hline AB-SA130 & Carboniferous-Permian & Unayzah Fm. & $26^{\circ} 55^{\prime} 35.5^{\prime \prime}$ & $43^{\circ} 34^{\prime} 38.8^{\prime \prime}$ & E of Qusaiba depressic \\
\hline AB-SA 150 & Devonian & Jubah Fm. & $29^{\circ} 58^{\prime} 14.2^{\prime \prime}$ & $40^{\circ} 10^{\prime} 19.4 "$ & W of Sakaka \\
\hline AB-SA152 & Devonian & Jubah Fm. & $29^{\circ} 58^{\prime} 17.7^{\prime \prime}$ & $40^{\circ} 10^{\prime} 21.0 "$ & W of Sakaka \\
\hline AB-SA153 & Devonian & Jubah Fm. & $29^{\circ} 58^{\prime} 18.4^{\prime \prime}$ & $40^{\circ} 10^{\prime} 26.1 "$ & W of Sakaka \\
\hline AB-SA160/T & Devonian & Jauf Fm. & $30^{\circ} 04^{\prime} 46.0^{\prime \prime}$ & $39^{\circ} 55^{\prime} 52.0^{\prime \prime}$ & Wadi Murayr \\
\hline AB-SA161 & Devonian & Jauf Fm. & $30^{\circ} 04^{\prime} 45.7^{\prime \prime}$ & $39^{\circ} 55^{\prime} 55.4^{\prime \prime}$ & Wadi Murayr \\
\hline AB-SA164 & Devonian & Jauf Fm. & $29^{\circ} 49^{\prime} 41.1^{\prime \prime}$ & $39^{\circ} 53^{\prime} 00.9^{\prime \prime}$ & Dawmut al Jandal \\
\hline AB-SA154 & Devonian & Tawil Fm. & $29^{\circ} 49^{\prime} 34.7^{\prime \prime}$ & $39^{\circ} 32^{\prime} 10.8^{\prime \prime}$ & W of Dawmut al Jandə \\
\hline AB-SA156 & Devonian & Tawil Fm. & $29^{\circ} 49^{\prime} 30.5^{\prime \prime}$ & $39^{\circ} 32^{\prime} 16.4^{\prime \prime}$ & W of Dawmut al Jand \\
\hline AB-SA157 & Devonian & Tawil Fm. & $29^{\circ} 49^{\prime} 29.3 "$ & $39^{\circ} 32^{\prime} 17.0^{\prime \prime}$ & W of Dawmut al Jand \\
\hline AB-SA 128 & Silurian & Sharawra Mbr. & $26^{\circ} 51^{\prime} 04.2^{\prime \prime}$ & $43^{\circ} 34^{\prime} 40.9^{\prime \prime}$ & W of Qusaiba depressi \\
\hline AB-SA127 & Silurian & Sharawra Mbr. & $26^{\circ} 51^{\prime} 05.5^{\prime \prime}$ & $43^{\circ} 34^{\prime} 42.3^{\prime \prime}$ & W of Qusaiba depressi \\
\hline AB-SA132/1 & Late Ordovician & Zarqa Fm. & $26^{\circ} 51^{\prime} 28.6^{\prime \prime}$ & $43^{\circ} 21^{\prime} 22.2^{\prime \prime}$ & NW of Al Qara \\
\hline AB-SA132/2 & Late Ordovician & Zarqa Fm. & $26^{\circ} 51^{\prime} 28.6^{\prime \prime}$ & $43^{\circ} 21^{\prime} 22.2^{\prime \prime}$ & NW of Al Qara \\
\hline AB-SA123/2 & Late Ordovician & Sarah Fm. & $26^{\circ} 23^{\prime} 02.4^{\prime \prime}$ & $43^{\circ} 45^{\prime} 41.8^{\prime \prime}$ & W of Al Qara \\
\hline AB-SA $122 / 2$ & Late Ordovician & Sarah Fm. & $26^{\circ} 23^{\prime} 03.8^{\prime \prime}$ & $43^{\circ} 45^{\prime} 41.2^{\prime \prime}$ & W of Al Qara \\
\hline AB-SA124 & Ordovician & Qasim Fm. & $26^{\circ} 23^{\prime} 25.1^{\prime \prime}$ & $43^{\circ} 46^{\prime} 22.3^{\prime \prime}$ & W of Al Qara \\
\hline AB-SA126 & Ordovician & Qasim Fm. & $26^{\circ} 34^{\prime} 10.4^{\prime \prime}$ & $43^{\circ} 22^{\prime} 02.7 ”$ & Sarah ridge \\
\hline AB-SA145 & Ordovician & Qasim Fm. & $27^{\circ} 43^{\prime} 14.2^{\prime \prime}$ & $41^{\circ} 45^{\prime} 01.3^{\prime \prime}$ & $\mathrm{N}$ of Hail \\
\hline AB-SA144/1 & Ordovician & Qasim Fm. & $27^{\circ} 40^{\prime} 09.0^{\prime \prime}$ & $41^{\circ} 45^{\prime} 55.5^{\prime \prime}$ & Hail \\
\hline AB-SA142/2 & Ordovician & Qasim Fm. & $27^{\circ} 40^{\prime} 57.1^{\prime \prime}$ & $41^{\circ} 43^{\prime} 12.5^{\prime \prime}$ & $\mathrm{N}$ of Hail \\
\hline AB-SA170 & Cambrian-Ordovician & Saq Fm. & $26^{\circ} 48^{\prime} 41.1^{\prime \prime}$ & $39^{\circ} 29^{\prime} 04.2^{\prime \prime}$ & along Highway 70 \\
\hline AB-SA167 & Cambrian-Ordovician & Saq Fm. & $26^{\circ} 48^{\prime} 51.6^{\prime \prime}$ & $38^{\circ} 31^{\prime} 03.6^{\prime \prime}$ & along Highway 70 \\
\hline AB-SA169 & Cambrian-Ordovician & Saq Fm. & $26^{\circ} 27^{\prime} 54.7^{\prime \prime}$ & $39^{\circ} 14^{\prime} 46.3^{\prime \prime}$ & along Highway 15 \\
\hline \multicolumn{6}{|l|}{ Wajid area } \\
\hline AB-SA98 & Carboniferous-Permian & Juwayl Fm. & $19^{\circ} 57^{\prime} 37.4^{\prime \prime}$ & $44^{\circ} 44^{\prime} 59.0^{\prime \prime}$ & Jabal Seab \\
\hline AB-SA80 & Carboniferous-Permian & Juwayl Fm. & $19^{\circ} 54^{\prime} 54.2^{\prime \prime}$ & $44^{\circ} 38^{\prime} 59.2^{\prime \prime}$ & Jabal Blehan \\
\hline AB-SA100 & Carboniferous-Permian & Juwayl Fm. & $19^{\circ} 57^{\prime} 37.1 "$ & $44^{\circ} 44^{\prime} 59.9^{\prime \prime}$ & Jabal Seab \\
\hline AB-SA87 & Devonian & Khusayyayn Fm. & $20^{\circ} 04^{\prime} 50.6^{\prime \prime}$ & $44^{\circ} 39^{\prime} 48.0^{\prime \prime}$ & Jabal Khusayyayn \\
\hline AB-SA89 & Devonian & Khusayyayn Fm. & $20^{\circ} 04^{\prime} 52.2^{\prime \prime}$ & $44^{\circ} 39^{\prime} 48.2^{\prime \prime}$ & Jabal Khusayyayn \\
\hline AB-SA90 & Devonian & Khusayyayn Fm. & $20^{\circ} 04^{\prime} 53.9^{\prime \prime}$ & $44^{\circ} 39^{\prime} 49.7^{\prime \prime}$ & Jabal Khusayyayn \\
\hline AB-SA118 & Devonian & Khusayyayn Fm. & $18^{\circ} 10^{\prime} 21.8^{\prime \prime}$ & $44^{\circ} 19^{\prime} 10.3^{\prime \prime}$ & Nawan \\
\hline AB-SA32 & Devonian & Khusayyayn Fm. & $18^{\circ} 14^{\prime} 55.0^{\prime \prime}$ & $44^{\circ} 27^{\prime} 34.0 "$ & Hima \\
\hline AB-SA115 & Silurian & Qusaiba Mbr. & $18^{\circ} 10^{\prime} 29.8^{\prime \prime}$ & $44^{\circ} 19^{\prime} 11.0^{\prime \prime}$ & Nawan \\
\hline AB-SA62 & Late Ordovician & Sanamah Fm. & $20^{\circ} 14^{\prime} 57.6^{\prime \prime}$ & $44^{\circ} 17^{\prime} 13.8^{\prime \prime}$ & Jabal Atheer \\
\hline AB-SA63 & Late Ordovician & Sanamah Fm. & $20^{\circ} 14^{\prime} 57.9^{\prime \prime}$ & $44^{\circ} 17^{\prime} 12.7^{\prime \prime}$ & Jabal Atheer \\
\hline AB-SA64 & Late Ordovician & Sanamah Fm. & $20^{\circ} 14^{\prime} 57.6^{\prime \prime}$ & $44^{\circ} 17^{\prime} 12.2^{\prime \prime}$ & Jabal Atheer \\
\hline AB-SA73 & Late Ordovician & Sanamah Fm. & $20^{\circ} 09^{\prime} 17.0 "$ & $44^{\circ} 09^{\prime} 53.9^{\prime \prime}$ & Jabal Nafla \\
\hline AB-SA74 & Cambrian-Ordovician & Dibsiyah Fm. & $20^{\circ} 09^{\prime} 15.5^{\prime \prime}$ & $44^{\circ} 09^{\prime} 53.3^{\prime \prime}$ & Jabal Nafla \\
\hline AB-SA76 & Cambrian-Ordovician & Dibsiyah Fm. & $20^{\circ} 09^{\prime} 15.1^{\prime \prime}$ & $44^{\circ} 09^{\prime} 51.8^{\prime \prime}$ & Jabal Nafla \\
\hline AB-SA72 & Cambrian-Ordovician & Dibsiyah Fm. & $20^{\circ} 09^{\prime} 10.6^{\prime \prime}$ & $44^{\circ} 09^{\prime} 45.3^{\prime \prime}$ & Jabal Nafla \\
\hline AB-SA69 & Cambrian-Ordovician & Dibsiyah Fm. & $20^{\circ} 14^{\prime} 57.6^{\prime \prime}$ & $44^{\circ} 17^{\prime} 06.3^{\prime \prime}$ & Jabal Atheer \\
\hline AB-SA79 & Cambrian-Ordovician & Dibsiyah Fm. & $20^{\circ} 09^{\prime} 16.7^{\prime \prime}$ & $44^{\circ} 09^{\prime} 34.4^{\prime \prime}$ & Jabal Nafla \\
\hline JUW & Carboniferous-Permian & Juwayl Fm. & $19^{\circ} 55^{\prime} 1.0 "$ & $44^{\circ} 38^{\prime} 57.0^{\prime \prime}$ & Jabal Blehan \\
\hline JUW-BAS & Carboniferous-Permian & Juwayl Fm. & $19^{\circ} 53^{\prime} 41.0^{\prime \prime}$ & $44^{\circ} 40^{\prime} 20.4^{\prime \prime}$ & Abu Ledam \\
\hline Wuh-1-4 & Carboniferous-Permian & Juwayl Fm. & $19^{\circ} 58^{\prime} 14.2^{\prime \prime}$ & $44^{\circ} 45^{\prime} 0.0^{\prime \prime}$ & Bani Ruhayah \\
\hline
\end{tabular}


Table 1 (continued)

\begin{tabular}{|c|c|c|c|c|c|}
\hline Sample no. & Age & Stratigraphy & Latitude & Longitude & Location \\
\hline Wuh-4-2 & Carboniferous-Permian & Juwayl Fm. & $19^{\circ} 53^{\prime} 41.0^{\prime \prime}$ & $44^{\circ} 40^{\prime} 20.4^{\prime \prime}$ & Abu Ledam \\
\hline Wuh-5-32-33 & Carboniferous-Permian & Juwayl Fm. & $19^{\circ} 50^{\prime} 28.4^{\prime \prime}$ & $44^{\circ} 37^{\prime} 26.5^{\prime \prime}$ & Jabal Abood \\
\hline KSA 25 & Devonian & Khusayyayn Fm. & $20^{\circ} 4^{\prime} 54.6 ”$ & $44^{\circ} 39^{\prime} 46.2^{\prime \prime}$ & Jabal Khusayyayn \\
\hline WKh-T-1 & Devonian & Khusayyayn Fm. & $20^{\circ} 4^{\prime} 54.6^{\prime \prime}$ & $44^{\circ} 39^{\prime} 46.2^{\prime \prime}$ & Jabal Khusayyayn \\
\hline WKh-T-12 & Devonian & Khusayyayn Fm. & $20^{\circ} 4^{\prime} 54.6 "$ & $44^{\circ} 39^{\prime} 46.2^{\prime \prime}$ & Jabal Khusayyayn \\
\hline WKh-T-8 & Devonian & Khusayyayn Fm. & $20^{\circ} 4^{\prime} 54.6 ”$ & $44^{\circ} 39^{\prime} 46.2^{\prime \prime}$ & Jabal Khusayyayn \\
\hline $\mathrm{S} 2$ & Late Ordovician & Sanamah Fm. & $20^{\circ} 13^{\prime} 13.8^{\prime \prime}$ & $44^{\circ} 15^{\prime} 51.8^{\prime \prime}$ & Jabal Sanamah \\
\hline WDSK-4 & Late Ordovician & Sanamah Fm. & $20^{\circ} 16^{\prime} 7.0^{\prime \prime}$ & $44^{\circ} 23^{\prime} 59.6 "$ & Jabal Atheer \\
\hline WDSK-5 & Late Ordovician & Sanamah Fm. & $20^{\circ} 16^{\prime} 7.0^{\prime \prime}$ & $44^{\circ} 23^{\prime} 59.6^{\prime \prime}$ & Jabal Atheer \\
\hline WDSK-5-b & Late Ordovician & Sanamah Fm. & $20^{\circ} 16^{\prime} 7.0^{\prime \prime}$ & $44^{\circ} 23^{\prime} 59.6 "$ & Jabal Atheer \\
\hline WDh-1-13 & Cambrian-Ordovician & Dibsiyah Fm. & $20^{\circ} 9^{\prime} 17.8^{\prime \prime}$ & $44^{\circ} 9^{\prime} 33.7^{\prime \prime}$ & Jabal Nafla \\
\hline WDh-1-52 & Cambrian-Ordovician & Dibsiyah Fm. & $20^{\circ} 9^{\prime} 17.8^{\prime \prime}$ & $44^{\circ} 9^{\prime} 33.7^{\prime \prime}$ & Jabal Nafla \\
\hline WDh-1-top & Cambrian-Ordovician & Dibsiyah Fm. & $20^{\circ} 9^{\prime} 17.8^{\prime \prime}$ & $44^{\circ} 9^{\prime} 33.7^{\prime \prime}$ & Jabal Nafla \\
\hline DIB & Cambrian-Ordovician & Dibsiyah Fm. & $20^{\circ} 9^{\prime} 17.8^{\prime \prime}$ & $44^{\circ} 9^{\prime} 33.7^{\prime \prime}$ & Jabal Nafla \\
\hline
\end{tabular}


Table 2

\begin{tabular}{|c|c|c|c|c|c|c|c|c|c|c|c|c|c|c|c|c|}
\hline Sample & Formation & Classification & Qm & Qmu & Qp & Plag & Afsp & Lf & Pore & $\begin{array}{l}\mathrm{PM}+ \\
\mathrm{Cem}\end{array}$ & $\begin{array}{l}\text { Total } \\
\text { counts }\end{array}$ & Accessories & MI & GS & Sorting & Rounding \\
\hline \multicolumn{17}{|c|}{ Tabuk area } \\
\hline 120 & Unayzah & Subarkose & 84 & 65 & 33 & 10 & 22 & 0 & 53 & 33 & 300 & $+\mathrm{zrn},+\mathrm{rt}$ & 0.85 & $\mathrm{mS}$ & Poor & $\begin{array}{l}\text { subang.- } \\
\text { md. }\end{array}$ \\
\hline 129 & Unayzah & $\begin{array}{l}\text { Quartz } \\
\text { arenite }\end{array}$ & 91 & 107 & 2 & 6 & 0 & 0 & 79 & 15 & 300 & & 0.97 & $\mathrm{mS}$ & Medium & $\begin{array}{l}\text { subrnd.- } \\
\text { md. }\end{array}$ \\
\hline 130 & Unayzah & Subarkose & 66 & 155 & 5 & 13 & 3 & 0 & 52 & 6 & 300 & & 0.93 & $\mathrm{mS}$ & Medium & $\begin{array}{l}\text { subrnd.- } \\
\text { md. }\end{array}$ \\
\hline 150 & Jubah & Subarkose & 126 & 40 & 3 & 12 & 40 & 0 & 30 & 49 & 300 & + rt., +tur & 0.76 & fS & Good & $\begin{array}{l}\text { subang.- } \\
\text { subroun. }\end{array}$ \\
\hline 152 & Jubah & Subarkose & 131 & 64 & 3 & 10 & 23 & 0 & 58 & 11 & 300 & + mica & 0.86 & $\mathrm{mS}$ & Good & $\begin{array}{l}\text { subang.- } \\
\text { submd. }\end{array}$ \\
\hline 153 & Jubah & Arkose & 133 & 42 & 1 & 2 & 54 & 0 & 46 & 22 & 300 & & 0.76 & $\mathrm{mS}$ & Good & $\begin{array}{l}\text { subang.- } \\
\text { submd. }\end{array}$ \\
\hline $160 / \mathrm{T}$ & Jauf & Arkose & 74 & 72 & 2 & 10 & 64 & 0 & 28 & 50 & 300 & + mica & 0.67 & $\mathrm{fS}$ & Good & $\begin{array}{l}\text { subang.- } \\
\text { submd. }\end{array}$ \\
\hline 161 & Jauf & Arkose & 83 & 75 & 5 & 8 & 39 & 0 & 39 & 51 & 300 & & 0.78 & $\mathrm{mS}$ & Good & $\begin{array}{l}\text { subang.- } \\
\text { md. }\end{array}$ \\
\hline 164 & Jauf & $\begin{array}{l}\text { Quartz } \\
\text { arenite }\end{array}$ & 90 & 75 & 13 & 0 & 0 & 0 & 5 & 117 & 300 & & 1.00 & $\mathrm{mS}$ & Poor & rounded \\
\hline 154 & Tawil & $\begin{array}{l}\text { Quartz } \\
\text { arenite }\end{array}$ & 200 & 80 & 11 & 0 & 0 & 0 & 9 & 0 & 300 & & 1.00 & $\mathrm{mS}$ & Medium & $\begin{array}{l}\text { subang.- } \\
\text { submd. }\end{array}$ \\
\hline 156 & Tawil & $\begin{array}{l}\text { Quartz } \\
\text { arenite }\end{array}$ & 79 & 115 & 1 & 0 & 0 & 0 & 54 & 51 & 300 & + +rt., + trn & 1.00 & $\mathrm{mS}$ & Medium & $\begin{array}{l}\text { subang.- } \\
\text { md. }\end{array}$ \\
\hline 157 & Tawil & Subarkose & 88 & 111 & 4 & 4 & 22 & 0 & 60 & 11 & 300 & $+\mathrm{zrn},+\mathrm{rt}$ & 0.89 & $\mathrm{mS}$ & Medium & subrounded \\
\hline 128 & Sharawra & Arkose & 56 & 77 & 3 & 53 & 7 & 0 & 22 & 56 & 300 & + mica & 0.69 & $\mathrm{cSi}$ & Good & subangular \\
\hline 127 & Sharawra & Arkose & 74 & 62 & 1 & 41 & 5 & 0 & 23 & 58 & 300 & + mica & 0.75 & $\mathrm{cSi}$ & Good & subangular \\
\hline $132 / 2$ & Zarqa & Subarkose & 105 & 110 & 2 & 11 & 5 & 0 & 43 & 24 & 300 & $++\mathrm{zrn}$ & 0.93 & $\mathrm{fS}$ & Medium & subrounded \\
\hline $132 / 1$ & Zarqa & Subarkose & 93 & 56 & 1 & 9 & 2 & 0 & 10 & 129 & 300 & & 0.93 & $\mathrm{fS}$ & Good & subangular \\
\hline $123 / 2$ & Sarah & Quartz arenite & 142 & 60 & 2 & 0 & 0 & 0 & 49 & 47 & 300 & & 1.00 & $\mathrm{mS}$ & Poor & $\begin{array}{l}\text { subang.- } \\
\text { md. }\end{array}$ \\
\hline $122 / 2$ & Sarah & Quartz arenite & 99 & 94 & 17 & 2 & 1 & 0 & 76 & 11 & 300 & $+\mathrm{rt} .,+\mathrm{zm}$ & 0.99 & fS & Medium & $\begin{array}{l}\text { subrnd.- } \\
\text { md. }\end{array}$ \\
\hline 124 & Qasim & Quartz arenite & 148 & 73 & 4 & 5 & 1 & 0 & 38 & 18 & 300 & + mica & 0.97 & $\mathrm{mS}$ & Good & subrounded \\
\hline 126 & Qasim & subarkose & 127 & 90 & 1 & 13 & 13 & 0 & 16 & 40 & 300 & $++\mathrm{zrn},+\mathrm{rt}$ & 0.89 & fS & Good & subangular \\
\hline 145 & Qasim & Quartz arenite & 93 & 94 & 36 & 1 & 0 & 2 & 45 & 29 & 300 & & 0.99 & $\mathrm{mS}$ & Poor & $\begin{array}{l}\text { subang.- } \\
\text { md. }\end{array}$ \\
\hline $142 / 2$ & Qasim & Quartz arenite & 93 & 106 & 9 & 3 & 0 & 0 & 14 & 75 & 300 & & 0.99 & $\mathrm{mS}$ & Poor & $\begin{array}{l}\text { subang.- } \\
\text { submd. }\end{array}$ \\
\hline $144 / 1$ & Qasim & Quartz arenite & 88 & 96 & 35 & 0 & 0 & 0 & 27 & 54 & 300 & $+\mathrm{rt}$ & 1.00 & $\mathrm{mS}$ & Medium & $\begin{array}{l}\text { subang.- } \\
\text { submd. }\end{array}$ \\
\hline 170 & Saq & Quartz arenite & 91 & 119 & 8 & 6 & 1 & 0 & 30 & 37 & 292 & & 0.97 & $\mathrm{mS}$ & Medium & subrounded \\
\hline 167 & Saq & Quartz arenite & 91 & 100 & 20 & 0 & 0 & 0 & 17 & 72 & 300 & $+\mathrm{rt}$ & 1.00 & $\mathrm{mS}$ & Poor & $\begin{array}{l}\text { subang.- } \\
\text { submd. }\end{array}$ \\
\hline 169 & Saq & Quartz arenite & 69 & 118 & 23 & 1 & 0 & 0 & 18 & 71 & 300 & & 1.00 & $\mathrm{mS}$ & Medium & $\begin{array}{l}\text { subang.- } \\
\text { md. }\end{array}$ \\
\hline \multicolumn{17}{|c|}{ Wajid area } \\
\hline 98 & Juwayl & Arkose & 83 & 13 & 3 & 58 & 15 & 0 & 0 & 128 & 300 & & 0.58 & $\mathrm{mS}$ & Good & $\begin{array}{l}\text { subang.- } \\
\text { submd. }\end{array}$ \\
\hline 80 & Juwayl & Quartz arenite & 116 & 88 & 34 & 0 & 0 & 12 & 22 & 28 & 300 & $\begin{array}{l}\text { + }+ \text { zrn },+r t .,+ \text { cpx } \\
\quad+\text { titanite, }+ \text { ol }\end{array}$ & 0.95 & $\mathrm{mS}$ & Poor & $\begin{array}{l}\text { subrnd.- } \\
\text { md. }\end{array}$ \\
\hline 100 & Juwayl & Quartz arenite & 127 & 59 & 11 & 0 & 0 & 0 & 62 & 41 & 300 & $++\mathrm{zrn}$ & 1.00 & $\mathrm{mS}$ & Medium & subrounded \\
\hline 87 & Khusayyayn & Subarkose & 130 & 49 & 11 & 7 & 28 & 0 & 37 & 38 & 300 & + mica, + zrn, + rt & 0.84 & $\mathrm{mS}$ & Good & subangular \\
\hline 89 & Khusayyayn & Subarkose & 105 & 108 & 5 & 5 & 17 & 2 & 50 & 8 & 300 & $+\mathrm{rt}$ & 0.90 & $\mathrm{mS}$ & Medium & $\begin{array}{l}\text { subang.- } \\
\text { submd. }\end{array}$ \\
\hline 90 & Khusayyayn & Subarkose & 81 & 107 & 15 & 8 & 11 & 1 & 62 & 15 & 300 & + mica, + opx,+ zrn & 0.91 & $\mathrm{mS}$ & Good & $\begin{array}{l}\text { subang.- } \\
\text { submd. }\end{array}$ \\
\hline
\end{tabular}


Table 2 (continued)

\begin{tabular}{|c|c|c|c|c|c|c|c|c|c|c|c|c|c|c|c|c|}
\hline Sample & Formation & Classification & Qm & Qmu & Qp & Plag & Afsp & $\mathrm{Lf}$ & Pore & $\begin{array}{l}\mathrm{PM}+ \\
\text { Cem }\end{array}$ & $\begin{array}{l}\text { Total } \\
\text { counts }\end{array}$ & Accessories & MI & GS & Sorting & Rounding \\
\hline 118 & Khusayyayn & Quartz arenite & 67 & 121 & 39 & 5 & 0 & 0 & 51 & 17 & 300 & + tur, + rt & 0.98 & $\mathrm{mS}$ & Medium & $\begin{array}{l}\text { subrnd- } \\
\text { well rnd. }\end{array}$ \\
\hline 32 & Khusayyayn & Quartz arenite & 87 & 127 & 12 & 2 & 1 & 0 & 42 & 29 & 300 & + mica & 0.99 & $\mathrm{mS}$ & Medim & $\begin{array}{l}\text { well } \\
\text { rounded }\end{array}$ \\
\hline 115 & Qusaiba & Arkose & 25 & 37 & 3 & 37 & 17 & 0 & 1 & 180 & 300 & & 0.55 & $\mathrm{mS}$ & Poor & subangular \\
\hline 62 & Sanamah & Sublitharenite & 74 & 96 & 28 & 1 & 4 & 18 & 58 & 21 & 300 & + rt., +zm & 0.90 & $\mathrm{mS}$ & Good & subrounded \\
\hline 63 & Sanamah & Quartz arenite & 74 & 132 & 21 & 3 & 2 & 3 & 57 & 8 & 300 & $+\mathrm{zrn},+\mathrm{rt} .,+\mathrm{bt}$ & 0.97 & $\mathrm{mS}$ & Poor & subrounded \\
\hline 64 & Sanamah & Quartz arenite & 94 & 114 & 11 & 0 & 0 & 2 & 16 & 29 & 266 & $+\mathrm{px}$ & 0.99 & $\mathrm{mS}$ & Poor & subrounded \\
\hline 73 & Sanamah & Quartz arenite & 75 & 135 & 5 & 0 & 0 & 0 & 50 & 35 & 300 & & 1.00 & fS & Good & $\begin{array}{l}\text { subang.- } \\
\text { submd. }\end{array}$ \\
\hline 74 & Dibsiyah & Quartz arenite & 95 & 132 & 10 & 6 & 0 & 0 & 47 & 10 & 300 & + rt., + zm, + mica & 0.98 & $\mathrm{mS}$ & Poor & $\begin{array}{l}\text { subang.- } \\
\text { submd. }\end{array}$ \\
\hline 76 & Dibsiyah & Quartz arenite & 90 & 118 & 5 & 4 & 1 & 0 & 78 & 4 & 300 & + zrn,,+ tur & 0.98 & $\mathrm{mS}$ & Good & subangular \\
\hline 72 & Dibsiyah & Quartz arenite & 123 & 34 & 24 & 0 & 1 & 0 & 10 & 59 & 300 & ++ mica & 0.99 & $\mathrm{mS}$ & Poor & $\begin{array}{l}\text { subang.- } \\
\text { submd. }\end{array}$ \\
\hline 69 & Dibsiyah & Quartz arenite & 98 & 123 & 13 & 0 & 0 & 1 & 44 & 21 & 300 & $\begin{array}{l}+ \text { bt, }+ \text { zm },+ \text { hbl } \\
\quad+\text { mica }\end{array}$ & 1.00 & $\mathrm{mS}$ & Poor & $\begin{array}{l}\text { subrnd.- } \\
\text { md. }\end{array}$ \\
\hline 79 & Dibsiyah & Quartz arenite & 103 & 90 & 3 & 3 & 0 & 0 & 25 & 76 & 300 & & 0.98 & fS & Good & $\begin{array}{l}\text { subang.- } \\
\text { submd. }\end{array}$ \\
\hline
\end{tabular}

Data was acquired by ribbon point counting; observed heavy minerals and accessories are listed under 'Accessories'; plus signs indicate abundance: + - present; ++ - abundant

PM pseudo matrix, Cem cement, bt biotite, cpx clinopyroxene, hbl hornblende, ol olivine, opx orthopyroxene, px pyroxene, rt rutile, tur tourmaline, zrn zircon, MI mineralogical maturity index, GS grain size, cSi coarse silt, fS fine sand, mS medium sand, rnd. rounded, subrnd. subrounded, subang. subangular 